Eur. J. Mineral.

2015, 27, 669-682

Published online 26 June 2015

\title{
Crystal chemistry of cation-exchanged forms of epistolite-group minerals. Part II. Vigrishinite and Zn-exchanged murmanite
}

INNA S. LYKOVA ${ }^{1, *}$, IGOR V. PEKOV ${ }^{1}$, NATALIA V. ZUBKOVA ${ }^{1}$, VASILIY O. YAPASKURT ${ }^{1}$, NADEZHDA A. CHERVONNAYA ${ }^{2}$, ANDREY A. ZOLOTAREV ${ }^{3}$ and GERALD GIESTER ${ }^{4}$

${ }^{1}$ Faculty of Geology, Moscow State University, Vorobievy Gory, 119991 Moscow, Russia

*Corresponding author, e-mail: innalykova@mail.ru

${ }^{2}$ Institute of Problems of Chemical Physics, RAS, Chernogolovka, Moscow Region 142432, Russia

${ }^{3}$ Department of Crystallography, St. Petersburg State University, University Emb. 7/9, 199034 St. Petersburg, Russia

${ }^{4}$ Institute of Mineralogy and Crystallography, University of Vienna, Althanstrasse 14 (UZA 2), 1090 Vienna, Austria

\begin{abstract}
The crystal structure of vigrishinite, an epistolite-group heterophyllosilicate with essential Zn, has been reinvestigated; the ideal end-member formula is revised to $\mathrm{Zn}_{2} \mathrm{Ti}_{4-x}\left(\mathrm{Si}_{2} \mathrm{O}_{7}\right)_{2} \mathrm{O}_{2}(\mathrm{OH}, \mathrm{F}, \mathrm{O})_{2}\left(\mathrm{H}_{2} \mathrm{O}, \mathrm{OH}, \square\right)_{4}$ with $x<1$. Structure models of $\mathrm{Zn}$-exchanged forms of murmanite after 5 and 24 hour experiments with $1 \mathrm{~N} \mathrm{ZnSO}_{4}$ solution at $90{ }^{\circ} \mathrm{C}$ have been obtained from single-crystal X-ray diffraction data. The structural formulae are ${ }^{[B 1]} \mathrm{Ca}_{0.04}\left\{\mathrm{Na}_{1.22}\left(\mathrm{Ti}_{1.19} \mathrm{Mn}_{0.60} \mathrm{Nb}_{0.21}\right)\right\}\left\{{ }^{[A 1, A 2]} \mathrm{Zn}_{1.03}\left(\mathrm{Ti}_{1.64} \mathrm{Nb}_{0.36}\right)\left[\mathrm{Si}_{2} \mathrm{O}_{7}\right]_{2}\right\} \mathrm{O}_{2}(\mathrm{O}, \mathrm{OH})_{2}$ $\left(\mathrm{H}_{2} \mathrm{O}\right)_{4}$ for vigrishinite and $\left\{\mathrm{Na}_{1.14}\left(\mathrm{Ti}_{1.45} \mathrm{Mn}_{0.50} \mathrm{Nb}_{0.05}\right)\right\}\left\{{ }^{[A 1]} \mathrm{Ca}_{0.77}{ }^{[A 2]} \mathrm{Zn}_{0.13}\left(\mathrm{Ti}_{1.85} \mathrm{Nb}_{0.15}\right)\left[\mathrm{Si}_{2} \mathrm{O}_{7}\right]_{2}\right\} \mathrm{O}_{2}(\mathrm{OH}, \mathrm{O})_{2}\left(\mathrm{H}_{2} \mathrm{O}\right)_{4}$ and ${ }^{[B 1} \mathrm{Zn}_{0.15}{ }^{[B 2]} \mathrm{Ca}_{0.18}\left\{\mathrm{Na}_{1.06}\left(\mathrm{Ti}_{1.32} \mathrm{Mn}_{0.60} \mathrm{Nb}_{0.08}\right)\right\}\left\{{ }^{[A 1]} \mathrm{Zn}_{0.70}{ }^{[A 2]} \mathrm{Ca}_{0.12}\left(\mathrm{Ti}_{1.74} \mathrm{Nb}_{0.26}\right)\left[\mathrm{Si}_{2} \mathrm{O}_{7}\right]_{2}\right\} \mathrm{O}_{2}(\mathrm{OH}, \mathrm{O})_{2}\left(\mathrm{H}_{2} \mathrm{O}\right)_{4}$ for the 5 and 24 hour $\mathrm{Zn}$-exchanged forms of murmanite, respectively (braces give successively the contents of the octahedral $O$ and heteropolyhedral $H$ sheets). The triclinic $(P-1)$ unit-cell parameters are respectively: $a=8.7127(17), 8.871(3), 8.748(2) \AA ; \quad b=8.6823(17), 8.844(6)$, 8.724(2) $\AA ; ;=11.746(2), 11.734(6), 11.675(3) \AA ; \alpha=91.481(4), 92.75(3), 92.503(13)^{\circ} ; \beta=98.471(4), 97.60(4), 97.846(13)^{\circ} ; \gamma=$ 105.474(4), 106.23(2), $105.875(13)^{\circ} ; V=845.0(3), 872.7(8), 845.9(4) \AA^{3}$. Our data (1) confirm that vigrishinite was formed as a result of natural ion-exchange of murmanite $\mathrm{Na}_{4} \mathrm{Ti}_{4}\left(\mathrm{Si}_{2} \mathrm{O}_{7}\right)_{2} \mathrm{O}_{4} \cdot 4 \mathrm{H}_{2} \mathrm{O}$ with $\mathrm{Zn}^{2+}$ in low-temperature solutions; (2) prove that direct transformation of lomonosovite $\mathrm{Na}_{4} \mathrm{Ti}_{4}\left(\mathrm{Si}_{2} \mathrm{O}_{7}\right)_{2} \mathrm{O}_{4} \cdot 2 \mathrm{Na}_{3} \mathrm{PO}_{4}$ into vigrishinite, without prior leaching of $\mathrm{Na}^{+}$and $\mathrm{PO}_{4}{ }^{3-}$ from the former and formation of murmanite, is unlikely; (3) suggest the following ion-exchange mechanism: during the early stage $\mathrm{Na}^{+}$leaches into the solution whereas $\mathrm{Ca}^{2+}$, a common admixture in murmanite, migrates into one of the sites in the $H$ sheet, leaving another site vacant for further entry of $\mathrm{Zn}$; in the next stage $\mathrm{Zn}^{2+}$ enters the emptied site in the $H$ sheet and, in small amount, into the interlayer whereas $\mathrm{Ca}^{2+}$ partly moves from the $H$ sheet into the interlayer; (4) show the transformation of the murmanite-type unit cell $(P-1 ; V \approx$ $440 \AA^{3}$ ) into the vigrishinite-type cell with $a$ and $b$ parameters corresponding to the $a b$ face diagonals of the former during the first stage of the exchange with $\mathrm{Zn}$, due to ordering in the $H$ sheet. New findings of vigrishinite in two pegmatites of the Lovozero massif, Kola peninsula, Russia (at Severnyi open pit, Mt. Alluaiv and at Pegmatite \#60, Mt. Karnasurt) in the same setting as at the type locality, i.e. only in close contact with cavities after dissolved sphalerite, show that the ion exchange in epistolite-group heterophyllosilicates is not uncommon in Nature. Our data indicate there is a continuous solid solution between murmanite and vigrishinite.
\end{abstract}

Key-words: lomonosovite; murmanite; vigrishinite; zvyaginite; heterophyllosilicate mineral; titanosilicate; ion exchange; crystal structure; peralkaline rock; Lovozero alkaline massif.

\section{Introduction}

Epistolite-group minerals are layered titano- and niobosilicates (heterophyllosilicates) of the bafertisite meroplesiotype series (Ferraris \& Gula, 2005) with crystal structures based on the three-sheet $\mathrm{HOH}$ block. Its central octahedral $O$ sheet, formed by close-packed $\mathrm{Na}$ - and $\mathrm{Ti}-$ centred octahedra, is sandwiched between two identical heteropolyhedral $H$ sheets consisting of alternating $\left[\mathrm{Si}_{2} \mathrm{O}_{7}\right]$ groups, Ti- or Nb-centred octahedra and $\mathrm{Na}$-centred eight-fold polyhedra. The interlayer space contains $\mathrm{Na}^{+}$cations and $\mathrm{PO}_{4}{ }^{3-}$ groups [lomonosovite
$\mathrm{Na}_{4} \mathrm{Ti}_{4}\left(\mathrm{Si}_{2} \mathrm{O}_{7}\right)_{2} \mathrm{O}_{4} \cdot 2 \mathrm{Na}_{3} \mathrm{PO}_{4}$, Belov et al., 1977] or $\mathrm{H}_{2} \mathrm{O}$ molecules [murmanite $\mathrm{Na}_{4} \mathrm{Ti}_{4}\left(\mathrm{Si}_{2} \mathrm{O}_{7}\right)_{2} \mathrm{O}_{4} \cdot 4 \mathrm{H}_{2} \mathrm{O}$ and epistolite $\mathrm{Na}_{4} \mathrm{Nb}_{2} \mathrm{Ti}\left(\mathrm{Si}_{2} \mathrm{O}_{7}\right)_{2} \mathrm{O}_{2}(\mathrm{OH}, \mathrm{F})_{2} \cdot 4 \mathrm{H}_{2} \mathrm{O}$, Khalilov, 1989; Sokolova \& Hawthorne, 2004]. Borneman-Starynkevich (1946) proved that $\mathrm{Na}^{+}$and $\mathrm{PO}_{4}{ }^{3-}$ can easily be leached from the interlayer of lomonosovite and replaced by $\mathrm{H}_{2} \mathrm{O}$ molecules, which results in its transformation to murmanite. Cationexchange experiments in aqueous solutions show the strong affinity and selectivity of these minerals for the chalcophile elements $\mathrm{Ag}, \mathrm{Cu}$ and $\mathrm{Zn}$ (Lykova et al., 2013a and b). 
In this paper we present the second part of a study on the crystal chemistry of cation-exchanged forms of epistolitegroup minerals. The first one (Lykova et al., 2015) covers Ag-exchanged murmanite and lomonosovite and $\mathrm{Cu}$ exchanged lomonosovite. This article reports on the crystal chemistry of the $\mathrm{Zn}$-bearing heterophyllosilicates.

Two new epistolite-group members were described recently, vigrishinite $\mathrm{Zn}_{2} \mathrm{Ti}_{4-x} \mathrm{Si}_{4} \mathrm{O}_{14}\left(\mathrm{OH}, \mathrm{H}_{2} \mathrm{O}, \square\right)_{8}$ with $x<1$ (Pekov et al., 2013) and zvyaginite $\mathrm{NaZnNb}_{2}$ $\mathrm{Ti}\left[\mathrm{Si}_{2} \mathrm{O}_{7}\right]_{2} \mathrm{O}(\mathrm{OH}, \mathrm{F})_{3}\left(\mathrm{H}_{2} \mathrm{O}\right)_{4+x}$ with $x<1$ (Pekov et al., 2014). They are the first heterophyllosilicates with species-defining zinc. Vigrishinite and zvyaginite are late-stage, low-temperature minerals formed in an altered peralkaline (hyperagpaitic) pegmatite at Mt. Malyi Punkaruaiv, Lovozero alkaline complex, Kola peninsula, Russia. Both were found in numerous specimens, but exclusively in intimate association with cavities after completely or partially dissolved sphalerite, whereas related heterophyllosilicates outside the neighbourhood of such cavities are represented by Zn-free murmanite and epistolite only. This prompted the hypothesis that vigrishinite and zvyaginite are products of $\mathrm{Zn}$ exchange for $\mathrm{Na}$ in murmanite and epistolite, respectively, and thus are the first example of products of natural ion exchange in heterophyllosilicates.

Both minerals are interesting from a crystal-chemical point of view. They show a different type of unit cell as compared to that of murmanite and epistolite, and $\mathrm{Zn}$ occupies essentially different sites in their structures - an issue that can be accounted for by local bond-valence features of vigrishinite and zvyaginite (Pekov et al., 2013, 2014).

The goals of this paper are: (1) to discuss the crystalchemical behaviour of exchangeable cations $(\mathrm{Zn}, \mathrm{Na}, \mathrm{Ca})$ in ion-exchange reactions, (2) to describe unit-cell transformations linked to the cation-exchange reactions of murmanite with $\mathrm{Zn}$, both natural (vigrishinite formation) and in the laboratory, and (3) to document the possible occurrence of ion exchange in heterophyllosilicates in Nature. In addition, the crystal structure of holotype vigrishinite had been refined to $R=17.1 \%$ due to the poor quality even of the best tested crystals (Pekov et al., 2013). The obtained model seemed to be correct; however, the assignment of large cations and $\mathrm{Zn}$ to partially vacant sites was questionable. The finding of a better-quality sample from the type locality was an additional incentive to revise the structure of vigrishinite.

\section{Experimental procedure}

\section{Analytical methods}

The chemical composition of untreated samples of murmanite and lomonosovite and their cation-exchanged forms was studied in Laboratory of local methods of matter investigation (Faculty of Geology, Moscow State University) with a Jeol JSM-6480LV scanning electron microscope equipped with INCA Energy 350 energy- dispersive spectrometer (EDS) and INCA Wave 500 wavelength-dispersive spectrometer (WDS) under the following conditions: operating voltage $20 \mathrm{kV}$, beam current $6.5 \mathrm{nA}$ and electron beam diameter $2 \mu \mathrm{m}$. The following standards were used: lorenzenite $(\mathrm{Na} K \alpha, \operatorname{Si} K \alpha, \operatorname{Ti} K \alpha)$, diopside $(\mathrm{Mg} K \alpha)$, wollastonite $(\mathrm{Ca} K \alpha)$, sanidine $(\mathrm{K} K \alpha)$, hornblende $(\mathrm{Al} K \alpha), \mathrm{GaP}(\mathrm{P} K \alpha), \mathrm{Nb}(\mathrm{Nb} L \alpha), \mathrm{Zr}(\mathrm{Zr} L \alpha), \mathrm{Mn}(\mathrm{Mn} K \alpha)$, orthopyroxene $(\mathrm{Fe} K \alpha)$ and $\mathrm{Zn}(\mathrm{Zn} K \alpha)$. Iron and manganese oxidation states and $\mathrm{H}_{2} \mathrm{O}$ content were not determined directly. Special emphasis was placed on the determination of the Na content because of the partial overlap of its analytical X-ray line $\mathrm{NaK} \alpha$ with the $\mathrm{Zn} L \alpha$ line. In order to do that, a compounded analysis was performed: $\mathrm{Na}$ content was measured using WDS mode while other elements using EDS mode and the $K \alpha$ analytical line was used for $\mathrm{Zn}$. Slight underestimation of $\mathrm{Na}$ (up to 1.0-1.5 wt.\% $\mathrm{Na}_{2} \mathrm{O}$ ) could be assumed due to the well known effect of its migration under high beam current.

The X-ray diffraction studies were carried out using single-crystal diffraction data collected in a full sphere of the reciprocal space on a Bruker Kappa X8 APEX diffractometer equipped with a CCD detector for the 5-hour Zn-exchanged form of murmanite and on a Bruker Kappa APEX DUO diffractometer equipped with a CCD detector for vigrishinite and the 24-hour $\mathrm{Zn}$-exchanged form of murmanite. The measured intensities were corrected for Lorentz, background, polarization and absorption effects.

\section{Initial samples and cation-exchange experiments}

All studied samples originate from the Lovozero and Khibiny alkaline complexes, Kola peninsula, Russia. Vigrishinite was initially described from the Pegmatite \#71, Mt. Malyi Punkaruaiv, Lovozero (Pekov et al., 2013). Recently, we identified the mineral in two other pegmatites from Lovozero: at the Severnyi (North) open pit of the abandoned Umbozero mine, Mt. Alluaiv, and at Pegmatite \#60, Mt. Karnasurt. In all three localities it forms lilac lamellar crystals up to $0.05 \times 1 \times 2 \mathrm{~cm}$, visually identical to murmanite. They are closely associated with cavities after dissolved sphalerite, commonly filled with the zinc smectite sauconite. The content of $\mathrm{Zn}$ in vigrishinite widely varies and reaches $18.8 \mathrm{wt} . \% \mathrm{ZnO}$. The new data show that this mineral forms a continuous solidsolution series with murmanite (Fig. 1). Typical chemical compositions are given in Table 1.

Murmanite samples for our experiments were collected from a hydrothermally altered peralkaline pegmatite at the above-mentioned Severnyi open pit in Lovozero. The mineral forms lilac lamellar crystals up to $0.05 \times 2.5 \times 3$ $\mathrm{cm}$ in the ussingite-microcline zone of the pegmatite. The lomonosovite samples originate from the huge unaltered peralkaline pegmatite Koashva-99 at Mt. Koashva, Khibiny (see description of these pegmatites in Pekov \& Nikolaev, 2013). It occurs as dark-brown to almost black tabular crystals up to $0.2 \times 2 \times 3.5 \mathrm{~cm}$, closely associated with aegirine, pectolite, villiaumite and thermonatrite. 


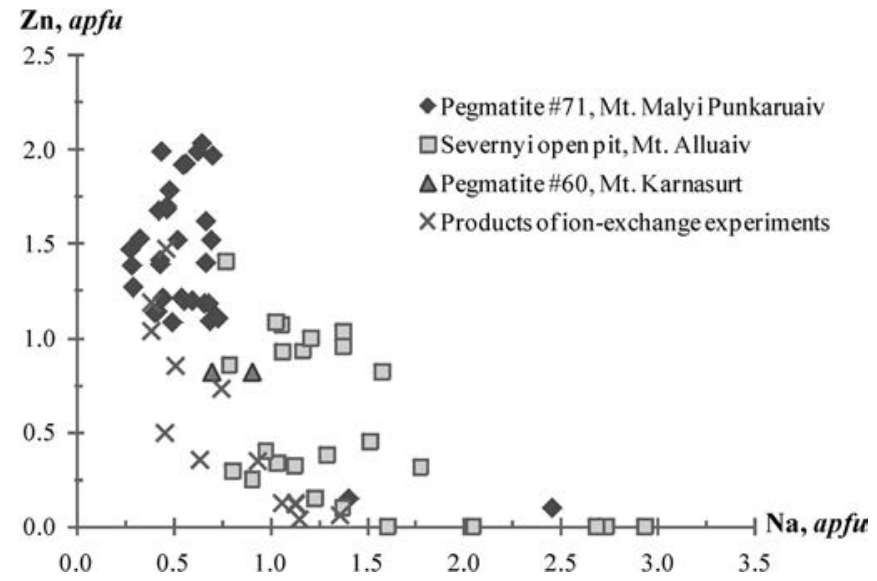

Fig. 1. Na and $\mathrm{Zn}$ contents (apfu, calculated on the basis of $4 \mathrm{Si}+\mathrm{Al}$ ) in members of the murmanite-vigrishinite solid-solution series from three peralkaline pegmatites within the Lovozero complex (based on 63 electron microprobe analyses) compared with products of ionexchange experiments for murmanite with $\mathrm{ZnSO}_{4}$ solution (13 electron microprobe analyses).
The ion-exchange experiments with murmanite were performed in Teflon containers at room temperature, at $60{ }^{\circ} \mathrm{C}$ and at $90{ }^{\circ} \mathrm{C}$ (Lykova et al., 2013a). The highest degree of exchange of $\mathrm{Na}$ for $\mathrm{Zn}$ was observed in the $90{ }^{\circ} \mathrm{C}$ experiments and this was a reason to choose this sample series for the crystal-structure study. A 5-10 mg portion of the mineral (fraction $0.5-2 \mathrm{~mm}$ ) was placed in $15 \mathrm{ml}$ of $1 \mathrm{~N}$ aqueous $\mathrm{ZnSO}_{4}$ solution. The reaction spreads over the entire grains volume within several hours, further increase in duration leads to a higher degree of exchange. The $\mathrm{Zn}$ distribution is uneven and varies from grain to grain. The $\mathrm{Zn}$ content in products of the 5-hour experiments varies from 0.1 to 0.7 atom per formula unit (apfu; all formulae are calculated on the basis of $4 \mathrm{Si}+\mathrm{Al}$ ) and the content of $\mathrm{Na}$ from 0.3 to $1.1 \mathrm{apfu}$, whereas murmanite initially contained 2.7-2.9 apfu Na (Table 1). After the 24-hour experiment, the Zn content reaches 0.9-1.2 apfu with a close to even distribution within grain; however, the $\mathrm{Zn}$ content remains low in some murmanite grains. The $\mathrm{Zn}$-exchanged form of murmanite inherits admixed $\mathrm{Ca}$ (0.5-0.7 apfu) from

Table 1. Chemical composition of murmanite, lomonosovite, products of their reactions with $\mathrm{ZnSO}_{4}$ solution, and vigrishinite.

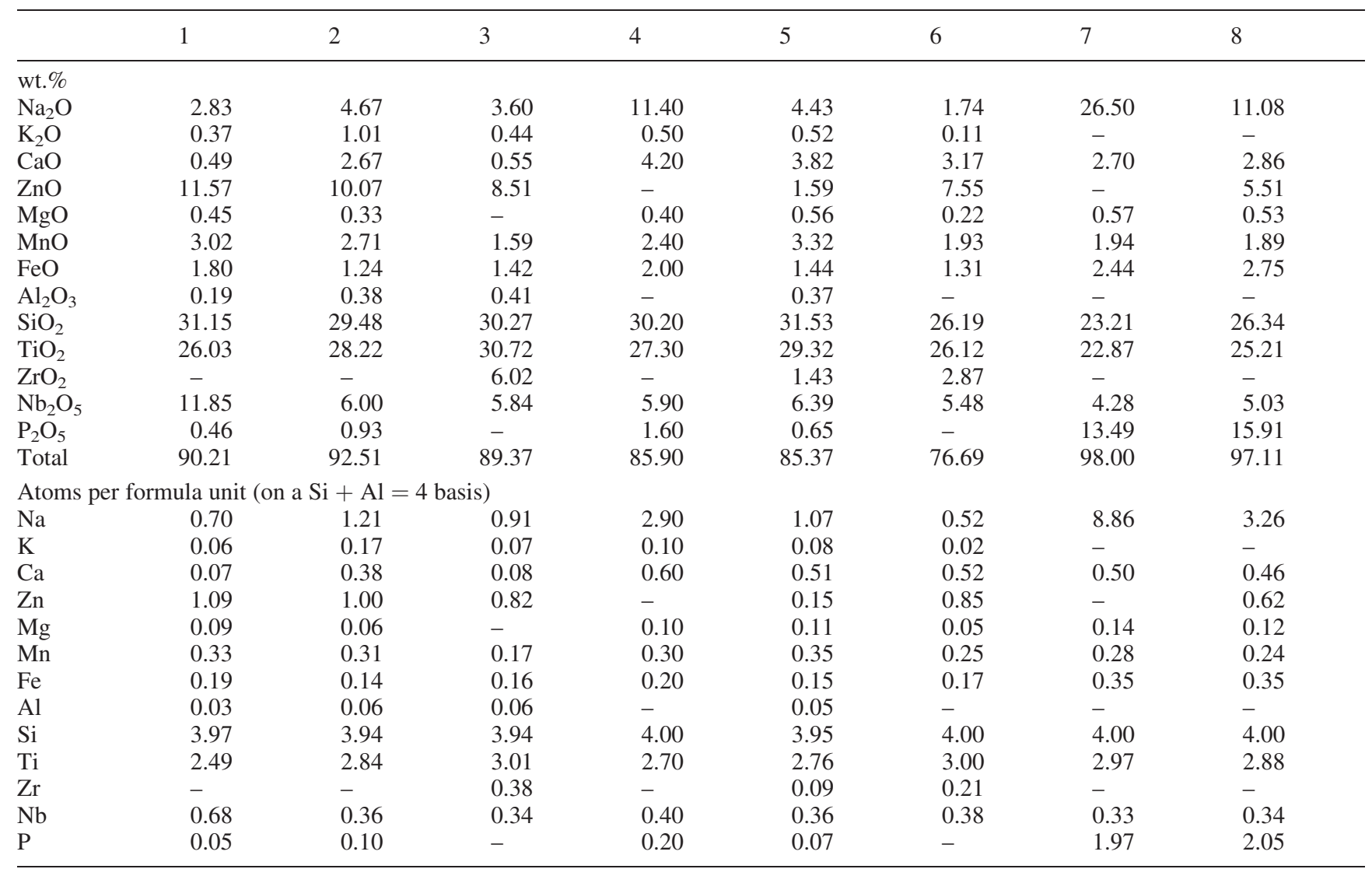

1-3-Vigrishinite: 1-Pegmatite \#71, Mt. Malyi Punkaruaiv, 2 - Severnyi open pit, Mt. Alluaiv, 3 - Pegmatite \#60, Mt. Karnasurt (all Lovozero alkaline complex, Kola peninsula, Russia). 4-6-Murmanite: 4-initial (Severnyi open pit, Mt. Alluaiv, Lovozero), 5-6-after ionexchange experiments with $\mathrm{ZnSO}_{4}$ solution at $90^{\circ} \mathrm{C}$ during $5 \mathrm{~h} \mathrm{(5)}$ and $24 \mathrm{~h} \mathrm{(6).} \mathrm{7-8-Lomonosovite:} \mathrm{7-initial} \mathrm{(Mt.} \mathrm{Koashva,} \mathrm{Khibiny),}$ 8 -after a ion-exchange experiment with $\mathrm{ZnSO}_{4}$ solution at $150^{\circ} \mathrm{C}$ during 5 days. Dash means the content of a constituent is below detection limit. 
the initial murmanite. Further increment of the experiment duration has not dramatic effect, but in 7 days the content of $\mathrm{Zn}$ reaches 1.5 apfu in some samples.

Lomonosovite did not show ion-exchange properties at $90{ }^{\circ} \mathrm{C}$ (for conditions, see above paragraph). For the experiments at $150{ }^{\circ} \mathrm{C}$, sealed glass ampoules were used. In the experiments with $1 \mathrm{~N}$ aqueous $\mathrm{ZnSO}_{4}$ solution, a $\mathrm{Zn}$ rich (up to $5.5 \mathrm{wt} . \% \mathrm{ZnO}$ ) phase was formed in which the $\mathrm{P}$ content (in atomic proportion) remains the same as in the initial lomonosovite, whereas the $\mathrm{Na}$ content decreases from 8.9 to 3.3 apfu (Table 1). The reaction was progressing slowly and it took several days to achieve 5-20 vol\% replacement of a grain (Fig. 2). During the experiment crystals of zinc sulfate grew on the surface and inside cleavage fractures of lomonosovite grains.

For the single-crystal X-ray diffraction study, products from the 5- and 24-hour experiments with murmanite in $\mathrm{ZnSO}_{4}$ solution were chosen, i.e. the forms with different degree of exchange of $\mathrm{Na}$ for $\mathrm{Zn}$.

\section{Single-crystal X-ray diffraction studies}

All crystal structures reported here were solved by direct methods and refined by full-matrix least-squares techniques on $F^{2}$ in the space group $P-1$ using the SHELX-97 program package (Sheldrick, 2008). The crystal data, the details of the X-ray diffraction studies and the structure refinement parameters are given in Table 2, atom coordinates, equivalent displacement parameters, site occupancy factors or refined site-scatterings, bond-valence sums (Brese \& O'Keeffe, 1991) and selected interatomic distances in Tables 3-8.

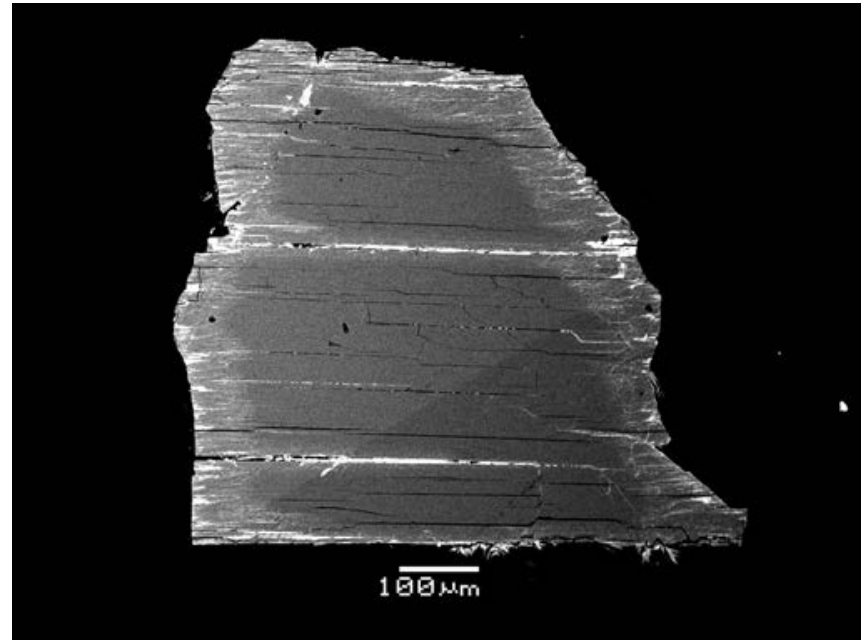

Fig. 2. Product of the reaction of lomonosovite with $1 \mathrm{~N} \mathrm{ZnSO}_{4}$ solution at $150{ }^{\circ} \mathrm{C}$ during 5 days. Lighter rim of the grain corresponds to the $\mathrm{Zn}$-exchanged form of lomonosovite, dark core is a relic of the initial mineral. The brightest phase along cleavage fractures is zinc sulfate precipitated from the solution during the experiment. SEM (BSE) image.

The crystal structure of vigrishinite was refined to $R=$ 0.1195 on the basis of 3458 unique reflections with $I>$ $2 \sigma(I)$, the Zn-exchanged forms of murmanite to $R=$ 0.1352 for the 5 -hour experiment (2378 independent reflections with $I>2 \sigma(I))$ and to $R=0.1707$ for the 24-hour experiment (1752 independent reflections with $I>2 \sigma(I)$ ).

The data sets for the samples are of relatively low quality due to (1) uneven distribution of $\mathrm{Zn}$ in the grain volume and (2) splitting of crystals along cleavage during the

Table 2. Crystal data, data-collection information and structure-refinement details for vigrishinite and Zn-exchanged forms of murmanite after experiments during 5 (ZnMur5h) and 24 hours (ZnMur24h).

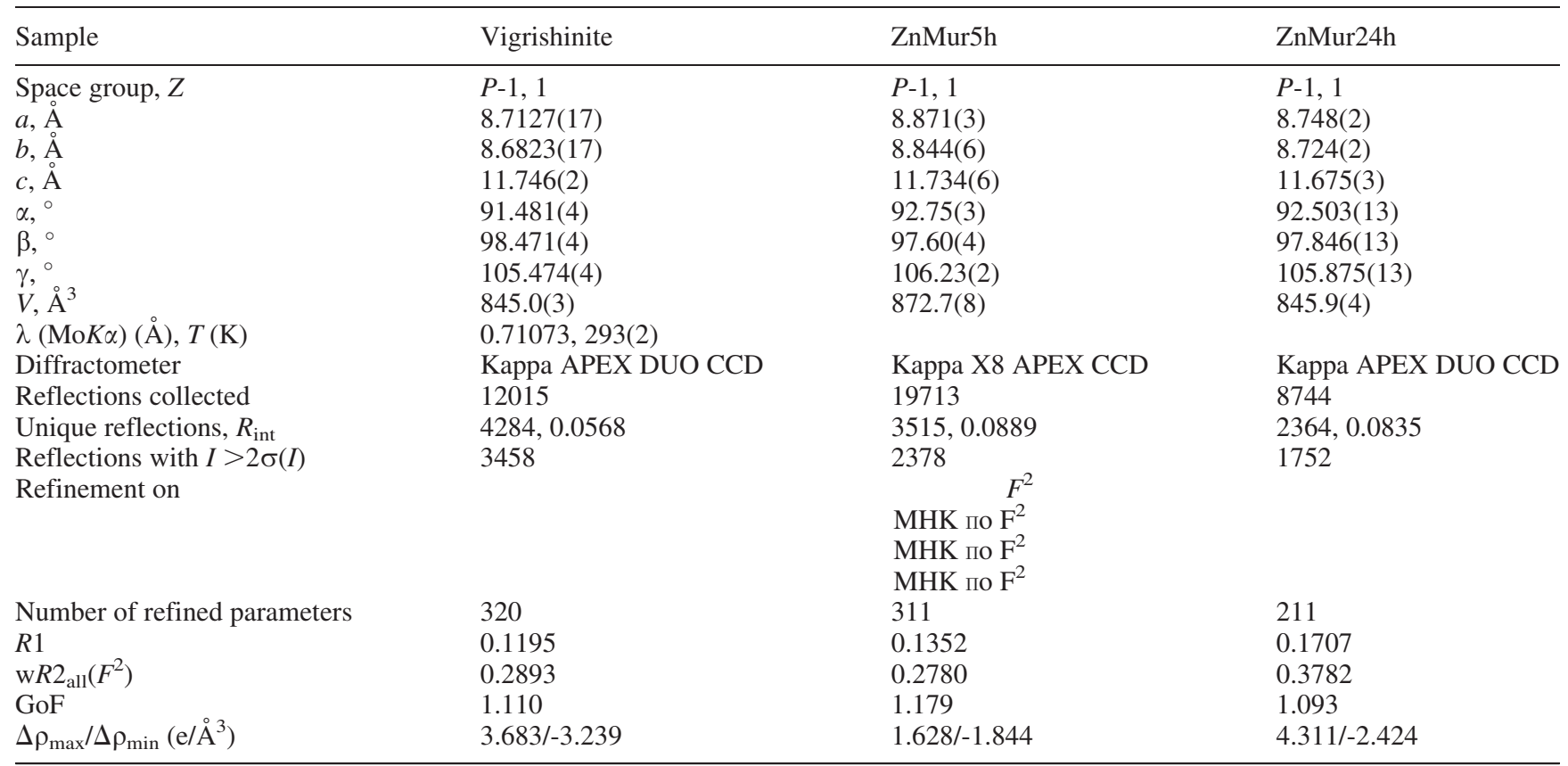


Table 3. Atom coordinates $(x, y, z)$, equivalent thermal displacement parameters $\left(U_{\text {eq }}, \AA^{2}\right)$, site occupancy factors (s.o.f.) and bond-valence sums (BVS) in the structure of vigrishinite.

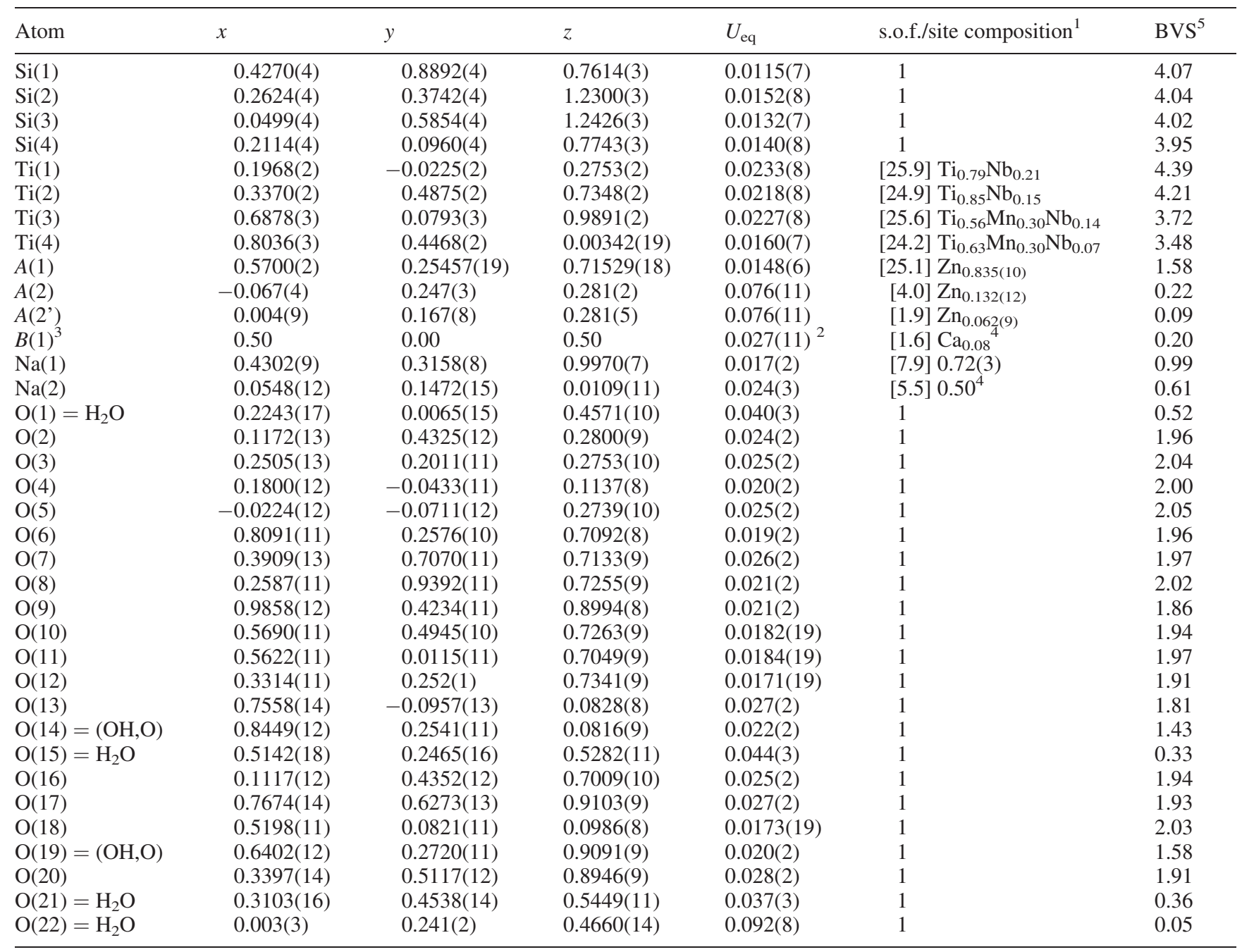

${ }^{1}$ Based on the $e_{\text {ref }}$ values (given in square brackets) and electron-microprobe data, taking into account coordination polyhedra character and interatomic distances.

${ }^{2} U_{\text {iso. }}$.

${ }^{3}$ Multiplicities of the $B(1)$ site is 1 , multiplicities of all other sites are 2.

${ }^{4}$ Values were fixed on the last stages of the refinement.

${ }^{5}$ BVS have been formally calculated taking into account s.o.f.

experiment, which results in diffuse reflections. Thus, we could not collect data suitable for structure refinement for products of the 7-day experiment because of their low quality.

However, in spite of high $R$, reasonable interatomic distances (Tables 4, 6 and 8), atom displacement parameters and bond valence sums (Tables 3, 5 and 7) could be obtained, showing the correctness of the structure models.

Because of the imperfection of crystals, there are several large residual electron-density peaks in the final difference maps of vigrishinite and the 24-hour $\mathrm{Zn}$-exchanged form of murmanite. In the former they are located around $\mathrm{Ti}(2)$ [3.68 and $\left.3.16 \mathrm{e} / \AA^{3}\right]$ and $\mathrm{Ti}(1)\left[2.43 \mathrm{e} / \AA^{3}\right]$ and in the latter around $\mathrm{Zn}(1)$ [4.31 and $\left.4.00 \mathrm{e} / \AA^{3}\right]$ and $\mathrm{Si}(2)\left[2.48\right.$ and $\left.2.39 \mathrm{e} / \AA^{3}\right]$.

\section{Crystal structures: description and discussion}

The crystal structure of murmanite was first examined by Khalilov et al. (1965) and repeatedly refined later, with space groups $P-1$ and $P 1$ (Rastsvetaeva \& Andrianov, 1986; Khalilov, 1989; Nemeth et al., 2005, and Cámara et al., 2008, who reviewed this history). The structural data on murmanite from the Severnyi open pit, Lovozero, the material source for our ion-exchange experiments, were reported by Lykova et al. (2015).

Two slightly different triclinic varieties of murmanite are known. Most authors described murmanite in a lomonosovite-like unit cell with $a$ and $b$ parameters close to 5.4 and 7.1 A, respectively. Unlike, Rastsvetaeva \& Andrianov (1986) observed a pseudo-periodicity along two axes and 
Table 4. Selected interatomic distances ( $)$ for vigrishinite.

\begin{tabular}{|c|c|c|c|c|c|c|c|c|c|c|c|}
\hline \multicolumn{3}{|c|}{$\mathrm{Si}(1)$-tetrahedron } & \multicolumn{3}{|c|}{$\mathrm{Si}(2)$-tetrahedron } & \multicolumn{3}{|c|}{$\mathrm{Si}(3)$-tetrahedron } & \multicolumn{3}{|c|}{$\mathrm{Si}(4)$-tetrahedron } \\
\hline \multirow[t]{4}{*}{$\overline{\mathrm{Si}(1)}$} & $-\mathrm{O}(11)$ & $1.599(9)$ & $\mathrm{Si}(2)$ & $-\mathrm{O}(3)$ & $1.590(10)$ & $\mathrm{Si}(3)$ & $-\mathrm{O}(6)$ & $1.597(10)$ & $\mathrm{Si}(4)$ & $-\mathrm{O}(12)$ & $1.604(9)$ \\
\hline & $-\mathrm{O}(7)$ & $1.599(10)$ & & $-\mathrm{O}(10)$ & $1.605(10)$ & & $-O(16)$ & $1.613(11)$ & & $-\mathrm{O}(5)$ & $1.615(10)$ \\
\hline & $-\mathrm{O}(18)$ & $1.635(10)$ & & $-\mathrm{O}(17)$ & $1.630(11)$ & & $-\mathrm{O}(2)$ & $1.634(10)$ & & $-\mathrm{O}(8)$ & $1.636(10)$ \\
\hline & $-\mathrm{O}(8)$ & $1.638(10)$ & & $-O(2)$ & $1.657(11)$ & & $-\mathrm{O}(9)$ & $1.646(10)$ & & $-\mathrm{O}(13)$ & $1.661(10)$ \\
\hline \multicolumn{2}{|c|}{$<\mathrm{Si}(1)-\mathrm{O}>$} & 1.62 & \multicolumn{2}{|c|}{$<\mathrm{Si}(2)-\mathrm{O}>$} & 1.62 & \multicolumn{2}{|c|}{$<\operatorname{Si}(3)-\mathrm{O}>$} & 1.62 & \multicolumn{2}{|c|}{$<\mathrm{Si}(4)-\mathrm{O}>$} & 1.63 \\
\hline \multicolumn{3}{|c|}{ Ti(1)-octahedron } & \multicolumn{3}{|c|}{ Ti(2)-octahedron } & \multicolumn{3}{|c|}{ Ti(3)-octahedron } & \multicolumn{3}{|c|}{ Ti(4)-octahedron } \\
\hline \multirow[t]{6}{*}{$\overline{\mathrm{Ti}(1)}$} & $-\mathrm{O}(5)$ & $1.840(10)$ & $\operatorname{Ti}(2)$ & $-\mathrm{O}(7)$ & $1.870(10)$ & $\operatorname{Ti}(3)$ & $-\mathrm{O}(4)$ & $1.862(10)$ & $\operatorname{Ti}(4)$ & $-\mathrm{O}(20)$ & $1.945(12)$ \\
\hline & $-\mathrm{O}(3)$ & $1.871(10)$ & & $-O(16)$ & $1.872(10)$ & & $-\mathrm{O}(14)$ & $1.930(10)$ & & $-\mathrm{O}(19)$ & $1.963(10)$ \\
\hline & $-\mathrm{O}(4)$ & $1.883(10)$ & & $-\mathrm{O}(20)$ & $1.879(11)$ & & $-\mathrm{O}(19)$ & $2.047(9)$ & & $-\mathrm{O}(17)$ & $2.000(11)$ \\
\hline & $-\mathrm{O}(6)$ & $2.042(9)$ & & $-\mathrm{O}(10)$ & $2.024(9)$ & & $-\mathrm{O}(13)$ & $2.061(11)$ & & $-\mathrm{O}(14)$ & $2.019(10)$ \\
\hline & $-\mathrm{O}(11)$ & $2.054(9)$ & & $-\mathrm{O}(12)$ & $2.032(9)$ & & $-\mathrm{O}(18)$ & $2.079(9)$ & & $-\mathrm{O}(9)$ & $2.037(10)$ \\
\hline & $-\mathrm{O}(1)$ & $2.114(12)$ & & $-\mathrm{O}(21)$ & $2.212(13)$ & & $-\mathrm{O}(18)$ & $2.090(10)$ & & $-\mathrm{O}(9)$ & $2.188(11)$ \\
\hline \multicolumn{2}{|c|}{$<\operatorname{Ti}(1)-\mathrm{O}>$} & 1.97 & \multicolumn{2}{|c|}{$<\operatorname{Ti}(2)-\mathrm{O}>$} & 1.98 & \multicolumn{2}{|c|}{$<\operatorname{Ti}(3)-\mathrm{O}>$} & 2.01 & \multicolumn{2}{|c|}{$<\operatorname{Ti}(4)-\mathrm{O}>$} & 2.03 \\
\hline \multicolumn{3}{|c|}{$\mathrm{Na}(1)$-octahedron } & \multicolumn{3}{|c|}{$\mathrm{Na}(2)$-octahedron } & \multicolumn{3}{|c|}{$A(1)$-octahedron } & \multicolumn{3}{|c|}{$B(1)$-octahedron } \\
\hline \multirow{6}{*}{$\mathrm{Na}(1)$} & $-\mathrm{O}(13)$ & $2.228(14)$ & $\mathrm{Na}(2)$ & $-\mathrm{O}(17)$ & $2.226(15)$ & $A(1)$ & $-\mathrm{O}(10)$ & $2.086(9)$ & $B(1)$ & $-\mathrm{O}(15)$ & $2.125(14) \times 2$ \\
\hline & $-\mathrm{O}(17)$ & $2.318(13)$ & & $-\mathrm{O}(13)$ & $2.245(15)$ & & $-\mathrm{O}(6)$ & $2.088(10)$ & & $-\mathrm{O}(11)$ & $2.381(10) \times 2$ \\
\hline & $-\mathrm{O}(20)$ & $2.330(13)$ & & $-\mathrm{O}(4)$ & $2.281(14)$ & & $-\mathrm{O}(11)$ & $2.093(9)$ & & $-\mathrm{O}(1)$ & $2.396(15) \times 2$ \\
\hline & $-\mathrm{O}(19)$ & $2.337(13)$ & & $-\mathrm{O}(4)$ & $2.463(16)$ & & $-\mathrm{O}(12)$ & $2.117(9)$ & & & \\
\hline & $-\mathrm{O}(20)$ & $2.346(13)$ & & $-\mathrm{O}(14)$ & $2.491(15)$ & & $-\mathrm{O}(15)$ & $2.175(13)$ & & & \\
\hline & $-\mathrm{O}(18)$ & $2.616(12)$ & & $-\mathrm{O}(9)$ & $2.920(16)$ & & $-\mathrm{O}(19)$ & $2.258(10)$ & & & \\
\hline \multicolumn{2}{|c|}{$<\mathrm{Na}(1)-\mathrm{O}>$} & 2.36 & \multicolumn{2}{|c|}{$<\mathrm{Na}(2)-\mathrm{O}>$} & 2.44 & $<A(1)$ & $-O>$ & 2.14 & \multicolumn{2}{|c|}{$<B(1)-\mathrm{O}>$} & 2.30 \\
\hline \multicolumn{3}{|c|}{$A(2)$-polyhedron* } & \multicolumn{3}{|c|}{$A\left(2^{\prime}\right)$-polyhedron* } & & & & & & \\
\hline \multirow[t]{5}{*}{$A(2)$} & $-\mathrm{O}(2)$ & $1.95(3)$ & $A\left(2^{\prime}\right)$ & $-\mathrm{O}(5)$ & $2.02(7)$ & & & & & & \\
\hline & $-\mathrm{O}(8)$ & $1.98(3)$ & & $-\mathrm{O}(3)$ & $2.10(8)$ & & & & & & \\
\hline & $-\mathrm{O}(22)$ & $2.17(3)$ & & $-\mathrm{O}(8)$ & $2.22(7)$ & & & & & & \\
\hline & $-\mathrm{O}(14)$ & $2.36(3)$ & & $-\mathrm{O}(2)$ & $2.25(6)$ & & & & & & \\
\hline & & & & $-\mathrm{O}(22)$ & $2.26(6)$ & & & & & & \\
\hline$<A(2$ & $\mathrm{O}>$ & 2.12 & $<A\left(2^{\prime}\right.$ & $-\mathrm{O}>$ & 2.17 & & & & & & \\
\hline
\end{tabular}

* Interatomic distances less than $2.7 \AA$ are listed.

chose a larger unit cell, with $a$ and $b$ parameters corresponding to the $a b$ face diagonals of the small murmanite unit-cell mentioned above (Table 9). Unfortunately, there is little to no information available about the origin of the studied sample and its chemical composition in the cited paper. No other mineral with this type of unit cell had been reported until the discovery of $\mathrm{Zn}$-dominant heterophyllosilicates. The unit cell of vigrishinite is similar to that of murmanite reported by Rastsvetaeva \& Andrianov (1986) and could be obtained from the small murmanite-type unit cell through the transformation matrix $(-1-1 \quad 0 /-1 \quad 1 \quad 0 / 0$ 0-1) (Fig. 3; Pekov et al., 2013). A similar feature is observed in the pair zvyaginite-epistolite. The unit cell of zvyaginite could be obtained from that of epistolite using the transformation ( $-1 \quad 10 / 1 \quad 10 / 00-1)$, and its $a$ and $b$ parameters correspond to the $a b$ face diagonals of the epistolite-type unit cell (Pekov et al., 2014).

All three samples studied in the present paper show additional systematic reflections in the reciprocal space, which were absent in the initial murmanite, thus leading us to choose large unit cells (Table 2). This feature was observed only for products of the ion exchange with $\mathrm{Zn}$ (both natural and obtained in the laboratory). Other cationexchanged forms of epistolite-group minerals, with $\mathrm{Cu}$ or
$\mathrm{Ag}$, do not show such unit-cell superstructures (Lykova et al., 2015).

\section{Vigrishinite}

The vigrishinite reported in this paper shows higher $\mathrm{Na}$ content than the holotype specimen described by Pekov et al. (2013). The structural data obtained confirm the original model; however, their better quality allowed us to unambiguously assign large cations and $\mathrm{Zn}$, unlike the "old" model. The base of the vigrishinite structure (Fig. 4(a), Table 3) is a three-sheet $\mathrm{HOH}$ block. The octahedral $O$ sheet is formed by the alternation of chains built by $\operatorname{Ti}(3)$ and $\operatorname{Ti}(4)$-centred octahedra with chains consisting of $\mathrm{Na}(1)$ and $\mathrm{Na}(2)$-centred polyhedra (Fig. 5(a)). Both sodium sites are partially vacant, with $72 \%$ and $50 \%$ occupancies for $\mathrm{Na}(1)$ and $\mathrm{Na}(2)$, respectively. The $O$ sheet is sandwiched between two heteropolyhedral $(H)$ sheets consisting of the $\mathrm{Si}_{2} \mathrm{O}_{7}$ groups alternating with $\mathrm{Ti}(1)$ and $\mathrm{Ti}(2)$-centred octahedra. At variance with the original vigrishinite model in which three of four titanium sites contained vacancies, all titanium sites are fully occupied and contain admixtures of 
Table 5. Atom coordinates $(x, y, z)$, equivalent thermal displacement parameters $\left(U_{\text {eq }}, \AA^{2}\right)$, site occupancy factors (s.o.f.) and bond-valence sums (BVS) in the structure of the Zn-exchanged form of murmanite (5 hour experiment).

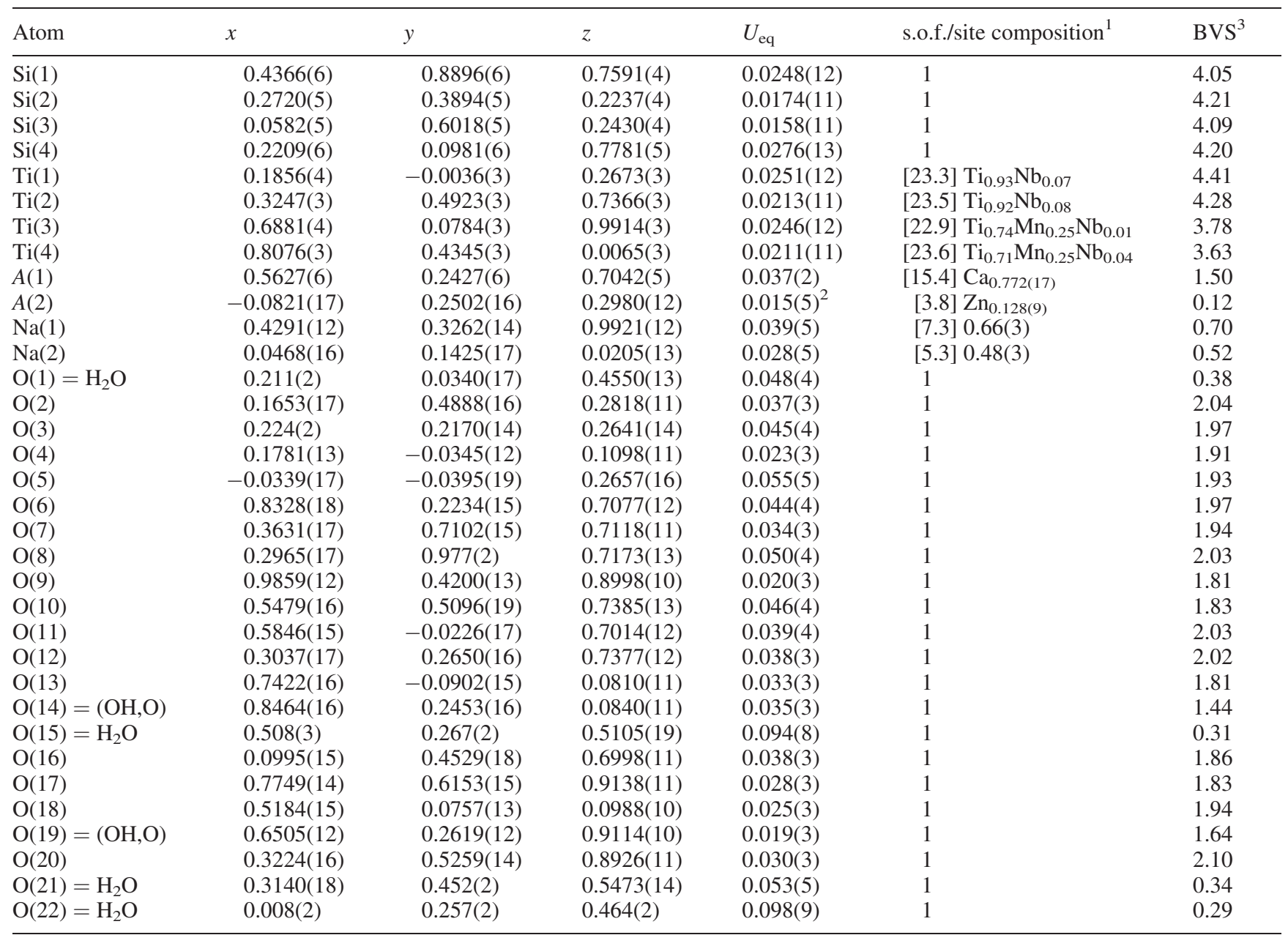

\footnotetext{
${ }^{1}$ Based on the $\mathrm{e}_{\text {ref }}$ values (given in square brackets) and electron-microprobe data, taking into account coordination polyhedra character and interatomic distances.

${ }^{2} U_{\text {iso }}$.

${ }^{3}$ BVS have been formally calculated taking into account s.o.f.
}

$\mathrm{Nb}$ and, for $\operatorname{Ti}(3)$ and $\operatorname{Ti}(4)$ sites, also the bivalent cations $\mathrm{Mn}, \mathrm{Fe}$ and $\mathrm{Mg}$. There are two sites $A(1)$ and $A(2)$ involved in the ion-exchange in the $H$ layer (Fig. 5(b)), corresponding to the $\mathrm{Na}$ site in the structure of murmanite with the small unit cell. Site $A(1)$ is occupied by $\mathrm{Zn}$ (83\% site occupancy). Occurrence of the smaller $\mathrm{Zn}$ instead of $\mathrm{Na}$ caused the decrease of $A(1)$ coordination number from 8 to 6 and the formation of an $A(1)$-centred octahedron with $<A(1)-\mathrm{O}>$ distance of $2.14 \AA$. It results in the distortion of neighbouring Ti-centred octahedra with formation of short $\mathrm{Ti}-\mathrm{O}$ bonds (Table 4). Alternating with $A(1)$, mainly vacant $A(2)$ sites occur in large cavities of the $H$ sheet (Fig. 5(b)). We found this site split into two sub-sites with occupancies 13 and $6 \%$ for $A(2)$ [with an $<A(2)-\mathrm{O}>$ distance of $2.12 \AA$ ] and $A\left(2^{\prime}\right)$ [with an $<A\left(2^{\prime}\right)-\mathrm{O}>$ distance of $2.17 \AA$ ] , respectively. But these sub-sites serve only as superpositions of "scattered" $\mathrm{Zn}^{1}$ and an accurate localization of $\mathrm{Zn}$ cations is not possible. There is one low-occupancy cation site $B(1)$ in the interlayer space, located on the inversion centre. This site, vacant in murmanite, is occupied most probably by $\mathrm{Ca}$ ( $8 \%$ site occupancy), which is a minor but common admixture confirmed by electronmicroprobe data in all studied samples from Mt. Malyi Punkaruaiv (e.g., Table 1, analysis \#1).

As shown by bond order calculations (Table 3), the anion sites $\mathrm{O}(1)$ to $\mathrm{O}(22)$ have different occupancies. The sites coordinating $\mathrm{Si}$ are occupied by $\mathrm{O}^{2-}$ anions $[\mathrm{O}(2)$, $\mathrm{O}(3), \mathrm{O}(5), \mathrm{O}(6), \mathrm{O}(7), \mathrm{O}(8), \mathrm{O}(9), \mathrm{O}(10), \mathrm{O}(11), \mathrm{O}(12)$, $\mathrm{O}(13), \mathrm{O}(16), \mathrm{O}(17)$ and $\mathrm{O}(18)]$ as well as the Ti-O-Ti bridges between $O$ and $H$ sheets $[\mathrm{O}(4)$ and $\mathrm{O}(20)]$. At the same time the sites corresponding to bridging anions $\mathrm{Ti}(3)$ $\mathrm{O}-\mathrm{Ti}(4)$ within the $O$ sheet have mixed occupancy $(\mathrm{OH}, \mathrm{O})$ $[\mathrm{O}(14)$ and $\mathrm{O}(19)]$. "Pendent" vertices of Ti- and $\mathrm{Zn}$ centred octahedra of the $H$ sheets, i.e. $\mathrm{O}(1), \mathrm{O}(15), \mathrm{O}(21)$ and $\mathrm{O}(22)$, are occupied by $\mathrm{H}_{2} \mathrm{O}$ molecules.

The formula of vigrishinite obtained from the structural refinement reported here is 
Table 6. Selected interatomic distances (Å) for the Zn-exchanged form of murmanite (5 hour experiment).

\begin{tabular}{|c|c|c|c|c|c|c|c|c|c|c|c|}
\hline \multicolumn{3}{|c|}{$\mathrm{Si}(1)$-tetrahedron } & \multicolumn{3}{|c|}{$\mathrm{Si}(2)$-tetrahedron } & \multicolumn{3}{|c|}{$\mathrm{Si}(3)$-tetrahedron } & \multicolumn{3}{|c|}{$\mathrm{Si}(4)$-tetrahedron } \\
\hline \multirow[t]{4}{*}{$\operatorname{Si}(1)$} & $-\mathrm{O}(7)$ & $1.579(13)$ & $\operatorname{Si}(2)$ & $-\mathrm{O}(3)$ & $1.578(13)$ & $\operatorname{Si}(3)$ & $-\mathrm{O}(16)$ & $1.595(14)$ & $\operatorname{Si}(4)$ & $-\mathrm{O}(12)$ & $1.580(15)$ \\
\hline & $-\mathrm{O}(11)$ & $1.582(14)$ & & $-\mathrm{O}(10)$ & $1.589(14)$ & & $-\mathrm{O}(2)$ & $1.603(13)$ & & $-\mathrm{O}(5)$ & $1.597(16)$ \\
\hline & $-\mathrm{O}(18)$ & $1.655(13)$ & & $-O(17)$ & $1.608(13)$ & & $-\mathrm{O}(6)$ & $1.609(13)$ & & $-\mathrm{O}(8)$ & $1.602(13)$ \\
\hline & $-\mathrm{O}(8)$ & $1.671(14)$ & & $-\mathrm{O}(2)$ & $1.648(14)$ & & $-\mathrm{O}(9)$ & $1.659(12)$ & & $-\mathrm{O}(13)$ & $1.652(14)$ \\
\hline \multicolumn{2}{|c|}{$<\operatorname{Si}(1)-\mathrm{O}>$} & 1.62 & \multicolumn{2}{|c|}{$<\operatorname{Si}(2)-\mathrm{O}>$} & 1.61 & \multicolumn{2}{|c|}{$<\operatorname{Si}(3)-\mathrm{O}>$} & 1.62 & \multicolumn{2}{|c|}{$<\mathrm{Si}(4)-\mathrm{O}>$} & 1.61 \\
\hline \multicolumn{3}{|c|}{ Ti(1)-octahedron } & \multicolumn{3}{|c|}{ Ti(2)-octahedron } & \multicolumn{3}{|c|}{ Ti(3)-octahedron } & \multicolumn{3}{|c|}{ Ti(4)-octahedron } \\
\hline \multirow[t]{6}{*}{$\overline{\operatorname{Ti}(1)}$} & $-\mathrm{O}(4)$ & $1.844(13)$ & $\operatorname{Ti}(2)$ & $-\mathrm{O}(20)$ & $1.844(13)$ & $\operatorname{Ti}(3)$ & $-\mathrm{O}(4)$ & $1.886(12)$ & $\operatorname{Ti}(4)$ & $-\mathrm{O}(20)$ & $1.844(13)$ \\
\hline & $-\mathrm{O}(5)$ & $1.881(15)$ & & $-O(7)$ & $1.904(13)$ & & $-\mathrm{O}(14)$ & $1.902(14)$ & & $-\mathrm{O}(19)$ & $1.937(11)$ \\
\hline & $-\mathrm{O}(3)$ & $1.887(13)$ & & $-\mathrm{O}(16)$ & $1.915(13)$ & & $-\mathrm{O}(19)$ & $1.993(14)$ & & $-\mathrm{O}(14)$ & $2.032(14)$ \\
\hline & $-\mathrm{O}(6)$ & $1.945(13)$ & & $-\mathrm{O}(10)$ & $1.940(14)$ & & $-\mathrm{O}(13)$ & $1.997(11)$ & & $-\mathrm{O}(17)$ & $2.041(12)$ \\
\hline & $-\mathrm{O}(11)$ & $1.968(13)$ & & $-\mathrm{O}(12)$ & $1.967(14)$ & & $-\mathrm{O}(18)$ & $2.070(13)$ & & $-\mathrm{O}(9)$ & $2.058(11)$ \\
\hline & $-\mathrm{O}(1)$ & $2.184(16)$ & & $-\mathrm{O}(21)$ & $2.218(16)$ & & $-\mathrm{O}(18)$ & $2.083(12)$ & & $-\mathrm{O}(9)$ & $2.170(11)$ \\
\hline \multicolumn{2}{|c|}{$<\operatorname{Ti}(1)-\mathrm{O}>$} & 1.95 & \multicolumn{2}{|c|}{$<\operatorname{Ti}(2)-\mathrm{O}>$} & 1.96 & \multicolumn{2}{|c|}{$<\operatorname{Ti}(3)-\mathrm{O}>$} & 1.99 & \multicolumn{2}{|c|}{$<\operatorname{Ti}(4)-\mathrm{O}>$} & 2.01 \\
\hline \multicolumn{3}{|c|}{$\mathrm{Na}(1)$-octahedron } & \multicolumn{3}{|c|}{$\mathrm{Na}(2)$-polyhedron } & \multicolumn{3}{|c|}{$A(1)$-polyhedron } & \multicolumn{3}{|c|}{$A(2)$-polyhedron } \\
\hline \multirow[t]{6}{*}{$\mathrm{Na}(1)$} & $-\mathrm{O}(13)$ & $2.261(18)$ & $\mathrm{Na}(2)$ & $-\mathrm{O}(4)$ & $2.284(18)$ & $A(1)$ & $-\mathrm{O}(15)$ & $2.29(2)$ & $A(2)$ & $-\mathrm{O}(22)$ & $2.00(3)$ \\
\hline & $-\mathrm{O}(17)$ & $2.400(16)$ & & $-\mathrm{O}(17)$ & $2.304(19)$ & & $-\mathrm{O}(11)$ & $2.407(16)$ & & $-\mathrm{O}(8)$ & $2.33(2)$ \\
\hline & $-\mathrm{O}(20)$ & $2.415(17)$ & & $-\mathrm{O}(14)$ & $2.39(2)$ & & $-\mathrm{O}(10)$ & $2.418(18)$ & & $-\mathrm{O}(14)$ & $2.503(19)$ \\
\hline & $-\mathrm{O}(19)$ & $2.479(15)$ & & $-\mathrm{O}(4)$ & $2.400(19)$ & & $-O(19)$ & $2.436(13)$ & & $-\mathrm{O}(7)$ & $2.60(2)$ \\
\hline & $-\mathrm{O}(20)$ & $2.493(17)$ & & $-\mathrm{O}(13)$ & $2.481(19)$ & & $-\mathrm{O}(12)$ & $2.441(15)$ & & $-\mathrm{O}(2)$ & $2.62(2)$ \\
\hline & $-\mathrm{O}(18)$ & $2.844(16)$ & & & & & $-O(6)$ & $2.444(18)$ & & $-\mathrm{O}(16)$ & $2.67(2)$ \\
\hline \multirow{3}{*}{\multicolumn{2}{|c|}{$<\mathrm{Na}(1)-\mathrm{O}>$}} & 2.48 & \multirow{3}{*}{\multicolumn{2}{|c|}{$<\mathrm{Na}(2)-\mathrm{O}>$}} & 2.37 & & $-\mathrm{O}(2)$ & $2.854(16)$ & \multirow{3}{*}{\multicolumn{2}{|c|}{$<A(2)-\mathrm{O}>$}} & 2.45 \\
\hline & & & & & & & $-\mathrm{O}(8)$ & $2.856(18)$ & & & \\
\hline & & & & & & $<A($ & $-\mathrm{O}>$ & 2.52 & & & \\
\hline
\end{tabular}

$$
\begin{aligned}
& { }^{[B 1]} \mathrm{Ca}_{0.04}\left\{\mathrm{Na}_{1.22}\left(\mathrm{Ti}_{1.19} \mathrm{Mn}_{0.60} \mathrm{Nb}_{0.21}\right)\right\} \\
& \quad\left\{{ }^{[A 1, A 2]} \mathrm{Zn}_{1.03}\left(\mathrm{Ti}_{1.64} \mathrm{Nb}_{0.36}\right)\left[\mathrm{Si}_{2} \mathrm{O}_{7}\right]_{2}\right\} \mathrm{O}_{2}(\mathrm{O}, \mathrm{OH})_{2}\left(\mathrm{H}_{2} \mathrm{O}\right)_{4}
\end{aligned}
$$

in which the braces give successively the contents of the $O$ and $H$ sheets.

\section{Zn-exchanged form of murmanite after 5-hour experiment}

Murmanite from the Severnyi open pit used for our ionexchange experiments contains significant $\mathrm{Ca}$ admixture, about 4 wt.\% $\mathrm{CaO}$ (Table 1, analysis \#4). The structure data (Lykova et al., 2015) show that $\mathrm{Ca}$ is located in the $\mathrm{Na}(2)$ site in the $H$ sheet. The structural refinement formula of the initial murmanite is $\left\{\mathrm{Na}_{1.68}\left(\mathrm{Ti}_{1.36} \mathrm{Mn}_{0.60} \mathrm{Nb}_{0.04}\right)\right\}$ $\left\{\mathrm{Na}_{1.00} \mathrm{Ca}_{0.60}\left(\mathrm{Ti}_{1.78} \mathrm{Nb}_{0.22}\right)\left[\mathrm{Si}_{2} \mathrm{O}_{7}\right]_{2}\right\} \mathrm{O}_{2}(\mathrm{O}, \mathrm{OH})_{2}\left(\mathrm{H}_{2} \mathrm{O}\right)_{4}$. However, the chemical composition of the initial murmanite varies from grain to grain; e.g., the $\mathrm{Ti}$ content ranges from 2.5 to $3.2 a p f u, \mathrm{Nb}-0.3-0.5$ apfu, $\mathrm{Zr}-$ 0.0-0.3 apfu. The electron-microprobe analysis of the grain of 5-hour Zn-exchanged murmanite used for structure data collection shows a small amount of $\mathrm{Zn}$ (0.1 apfu), a lower content of $\mathrm{Na}(1.1 \mathrm{apfu})$ as compared to initial murmanite (2.9 apfu) and an unchanged Ca content (Table 1, analysis \#5). Despite the small degree of exchange, the unit cell found for this sample belongs to the same type as that of vigrishinite (Table 2). The topology of the main structural $\mathrm{HOH}$ block of the Zn-exchanged form of murmanite and of vigrishinite is the same (Table 5, Fig. 4(b)). There are two partially vacant sodium sites in the $O$ sheet, with $66 \%$ and $48 \%$ occupancies for $\mathrm{Na}(1)$ and $\mathrm{Na}(2)$, respectively, whereas the sodium site in the $O$ sheet of the initial murmanite was fully occupied. The $A(1)$ site in the $H$ sheet is occupied by $\mathrm{Ca}$ (77\% site occupancy) forming an A(1)-centred distorted eight-fold polyhedron (Table 6, Fig. 6(a)). The $A(2)$ site is mainly vacant with "scattered" Zn (13\% site occupancy). There are no cations in the interlayer space. The occupancies of $\mathrm{O}(1)$ - $\mathrm{O}(22)$ anion sites are similar to those of vigrishinite.

The formula obtained from the structural refinement of the 5-hour Zn-exchanged form of murmanite is

$$
\begin{aligned}
& \left\{\mathrm{Na}_{1.14}\left(\mathrm{Ti}_{1.45} \mathrm{Mn}_{0.50} \mathrm{Nb}_{0.05}\right)\right\} \\
& \quad\left\{{ }^{\left[{ }_{1}\right]} \mathrm{Ca}_{0.77}^{[A 2]} \mathrm{Zn}_{0.13}\left(\mathrm{Ti}_{1.85} \mathrm{Nb}_{0.15}\right)\left[\mathrm{Si}_{2} \mathrm{O}_{7}\right]_{2}\right\} \mathrm{O}_{2}(\mathrm{OH}, \mathrm{O})_{2}\left(\mathrm{H}_{2} \mathrm{O}\right)_{4}
\end{aligned}
$$

in which the braces give successively the contents of the $O$ and $H$ sheets.

Thus, the early stage of ion-exchange is characterized by complete sodium leaching from the $H$ sheet, partial sodium leaching from the $O$ sheet, and (the most interesting feature) the unchanged calcium content moving into one of the sites of the $H$ sheet. This cation-vacancy ordering results in the formation of two crystallographically nonequivalent sites $A(1)$ and $A(2)$ in the $H$ sheet and the transformation of the murmanite-type unit cell into the vigrishinite-type one. As shown by Lykova et al. (2015), the $\mathrm{Ca}^{2+}$ cations, partially substituting $\mathrm{Na}^{+}$in the initial murmanite and lomonosovite, are rigidly fixed in their 
Table 7. Atom coordinates $(x, y, z)$, equivalent thermal displacement parameters $\left(U_{\text {eq }}, \AA^{2}\right)$, site occupancy factors (s.o.f.) and bond-valence sums (BVS) in the structure of the Zn-exchanged form of murmanite ( 24 hour experiment).

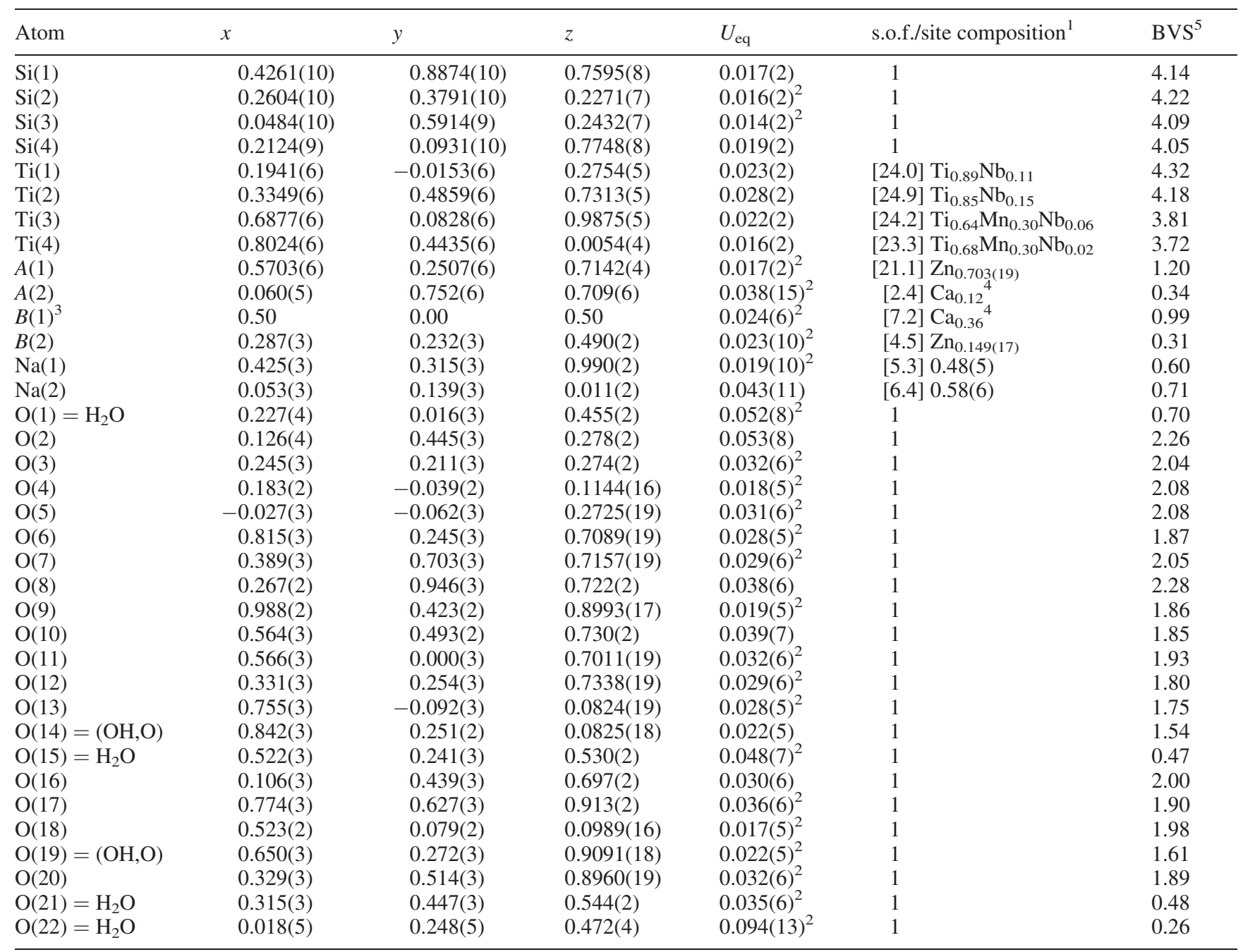

\footnotetext{
${ }^{1}$ Based on the $\mathrm{e}_{\text {ref }}$ values (given in square brackets) and electron-microprobe data, taking into account coordination polyhedra character and interatomic distances.

${ }^{2} U_{\text {iso. }}$

${ }^{3}$ Multiplicities of the $B(1)$ site is 1 , multiplicities of all other sites are 2.

${ }^{4}$ Values were fixed on the last stages of the refinement.

${ }^{5}$ BVS have been formally calculated taking into account s.o.f.
}

structural sites and are almost "inert" during ion-exchange at these conditions. Remaining in the Zn-exchanged form of murmanite, $\mathrm{Ca}$ redistributes in the structure, making "free" a site for further Zn entry. The charge deficiency caused by $\mathrm{Na}^{+}$leaching in the cation-exchanged phase is compensated by protonation of the bridging $\mathrm{O}$ atoms in $\mathrm{Ti}(3)-\mathrm{O}-\mathrm{Ti}(4)$ in the $O$ sheet [this is clearly confirmed by bond-valence sums for the $\mathrm{O}(14)$ and $\mathrm{O}(19)$ sites: 1.44 and 1.64 valence units, respectively: Table 5].

We assume this first stage of an ion-exchange process as a "preparation step" for zinc entry and this probably happens also in Nature. There are samples with Zn content less then 0.5 apfu (Fig. 1), which should be defined formally as Zn-rich varieties of murmanite; they overlap on the diagram with products of our laboratory experiments and, most likely, share their crystal chemical features, namely vigrishinite-type unit cell and the ordering in the $H$ sheet.

\section{Zn-exchanged form of murmanite after 24-hour experiment}

The topology of the main structural $\mathrm{HOH}$ block of the 24-hour Zn-exchanged form of murmanite remains the same as in the initial mineral (Table 7, Fig. 4(c)). Two sodium sites in the $O$ sheet are partially vacant with $48 \% \mathrm{Na}(1)$ and $58 \% \mathrm{Na}(2)$ occupancies. As in 
Table 8. Selected interatomic distances ( $\mathrm{A})$ for the Zn-exchanged form of murmanite (24 hour experiment).

\begin{tabular}{|c|c|c|c|c|c|c|c|c|c|c|c|}
\hline \multicolumn{3}{|c|}{$\mathrm{Si}(1)$-tetrahedron } & \multicolumn{3}{|c|}{$\mathrm{Si}(2)$-tetrahedron } & \multicolumn{3}{|c|}{$\mathrm{Si}(3)$-tetrahedron } & \multicolumn{3}{|c|}{$\mathrm{Si}(4)$-tetrahedron } \\
\hline \multirow[t]{4}{*}{$\operatorname{Si}(1)$} & $-\mathrm{O}(11)$ & $1.59(2)$ & $\operatorname{Si}(2)$ & $-\mathrm{O}(3)$ & $1.57(2)$ & $\mathrm{Si}(3)$ & $-\mathrm{O}(16)$ & $1.57(2)$ & $\operatorname{Si}(4)$ & $-\mathrm{O}(5)$ & $1.58(2)$ \\
\hline & $-\mathrm{O}(7)$ & $1.60(2)$ & & $-\mathrm{O}(2)$ & $1.61(3)$ & & $-\mathrm{O}(6)$ & $1.61(2)$ & & $-\mathrm{O}(8)$ & $1.62(2)$ \\
\hline & $-\mathrm{O}(8)$ & $1.621(16)$ & & $-\mathrm{O}(17)$ & $1.61(2)$ & & $-\mathrm{O}(9)$ & $1.64(2)$ & & $-\mathrm{O}(12)$ & $1.63(2)$ \\
\hline & $-\mathrm{O}(18)$ & $1.64(2)$ & & $-\mathrm{O}(10)$ & $1.63(2)$ & & $-\mathrm{O}(2)$ & $1.65(2)$ & & $-\mathrm{O}(13)$ & $1.65(2)$ \\
\hline \multicolumn{2}{|c|}{$<\mathrm{Si}(1)-\mathrm{O}>$} & 1.61 & \multicolumn{2}{|c|}{$<\operatorname{Si}(2)-\mathrm{O}>$} & 1.61 & \multicolumn{2}{|c|}{$<\operatorname{Si}(3)-\mathrm{O}>$} & 1.62 & \multicolumn{2}{|c|}{$<\mathrm{Si}(4)-\mathrm{O}>$} & 1.62 \\
\hline \multicolumn{3}{|c|}{ Ti(1)-octahedron } & \multicolumn{3}{|c|}{$\mathrm{Ti}(2)$-octahedron } & \multicolumn{3}{|c|}{ Ti(3)-octahedron } & \multicolumn{3}{|c|}{ Ti(4)-octahedron } \\
\hline \multirow[t]{6}{*}{$\operatorname{Ti}(1)$} & $-\mathrm{O}(5)$ & $1.86(2)$ & $\operatorname{Ti}(2)$ & $-\mathrm{O}(7)$ & $1.84(2)$ & $\operatorname{Ti}(3)$ & $-\mathrm{O}(4)$ & $1.84(2)$ & $\operatorname{Ti}(4)$ & $-\mathrm{O}(20)$ & $1.83(2)$ \\
\hline & $-\mathrm{O}(4)$ & $1.87(2)$ & & $-\mathrm{O}(16)$ & $1.91(2)$ & & $-\mathrm{O}(14)$ & $1.89(2)$ & & $-\mathrm{O}(19)$ & $1.91(2)$ \\
\hline & $-\mathrm{O}(3)$ & $1.90(2)$ & & $-\mathrm{O}(20)$ & $1.94(2)$ & & $-\mathrm{O}(19)$ & $2.00(2)$ & & $-\mathrm{O}(17)$ & $2.02(2)$ \\
\hline & $-\mathrm{O}(6)$ & $2.00(2)$ & & $-\mathrm{O}(10)$ & $1.99(2)$ & & $-\mathrm{O}(18)$ & $2.06(2)$ & & $-\mathrm{O}(14)$ & $2.03(2)$ \\
\hline & $-\mathrm{O}(11)$ & $2.05(2)$ & & $-\mathrm{O}(12)$ & $2.02(2)$ & & $-\mathrm{O}(18)$ & $2.09(2)$ & & $-\mathrm{O}(9)$ & $2.03(2)$ \\
\hline & $-\mathrm{O}(1)$ & $2.07(3)$ & & $-\mathrm{O}(21)$ & $2.18(2)$ & & $-\mathrm{O}(13)$ & $2.09(2)$ & & $-\mathrm{O}(9)$ & $2.21(2)$ \\
\hline \multicolumn{2}{|c|}{$<\operatorname{Ti}(1)-\mathrm{O}>$} & 1.96 & \multicolumn{2}{|c|}{$<\operatorname{Ti}(2)-\mathrm{O}>$} & 1.98 & \multicolumn{2}{|c|}{$<\operatorname{Ti}(3)-\mathrm{O}>$} & 2.00 & \multicolumn{2}{|c|}{$<\operatorname{Ti}(4)-\mathrm{O}>$} & 2.01 \\
\hline \multicolumn{3}{|c|}{$\mathrm{Na}(1)$-octahedron } & \multicolumn{3}{|c|}{$\mathrm{Na}(2)$-polyhedron } & \multicolumn{3}{|c|}{$A(1)$-polyhedron } & \multicolumn{3}{|c|}{$A(2)$ polyhedron } \\
\hline \multirow[t]{6}{*}{$\mathrm{Na}(1)$} & $-\mathrm{O}(13)$ & $2.19(3)$ & \multirow[t]{5}{*}{$\mathrm{Na}(2)$} & $-\mathrm{O}(4)$ & $2.19(3)$ & \multirow[t]{6}{*}{$A(1)$} & $-\mathrm{O}(15)$ & $2.12(3)$ & $A(2)$ & $-\mathrm{O}(2)$ & $2.05(4)$ \\
\hline & $-\mathrm{O}(17)$ & $2.36(3)$ & & $-\mathrm{O}(17)$ & $2.36(3)$ & & $-\mathrm{O}(10)$ & $2.13(2)$ & & $-\mathrm{O}(8)$ & $2.09(2)$ \\
\hline & $-\mathrm{O}(20)$ & $2.38(3)$ & & $-\mathrm{O}(14)$ & $2.38(3)$ & & $-\mathrm{O}(12)$ & $2.15(2)$ & & $-\mathrm{O}(22)$ & $2.12(8)$ \\
\hline & $-\mathrm{O}(19)$ & $2.40(3)$ & & $-\mathrm{O}(4)$ & $2.40(3)$ & & $-\mathrm{O}(6)$ & $2.17(2)$ & & $-\mathrm{O}(14)$ & $2.48(7)$ \\
\hline & $-\mathrm{O}(20)$ & $2.43(3)$ & & $-\mathrm{O}(13)$ & $2.43(3)$ & & $-\mathrm{O}(11)$ & $2.18(2)$ & & $-\mathrm{O}(5)$ & $2.80(7)$ \\
\hline & $-\mathrm{O}(18)$ & $2.73(3)$ & \multirow{3}{*}{\multicolumn{2}{|c|}{$<\mathrm{Na}(2)-\mathrm{O}>$}} & 2.35 & & $-\mathrm{O}(19)$ & $2.27(2)$ & & $-\mathrm{O}(3)$ & $2.81(6)$ \\
\hline \multirow{2}{*}{\multicolumn{2}{|c|}{$<\mathrm{Na}(1)-\mathrm{O}>$}} & 2.42 & & & & \multirow{2}{*}{\multicolumn{2}{|c|}{$<A(1)-\mathrm{O}>$}} & 2.17 & & $-\mathrm{O}(16)$ & $2.88(7)$ \\
\hline & & & & & & & & & $<A(2)$ & $\mathrm{O}>$ & 2.46 \\
\hline$B(1)-\mathrm{o}$ & hedron & & $B(2)$-o & hedron & & & & & & & \\
\hline$\overline{B(1)}$ & $-\mathrm{O}(15)$ & $2.07(3) \times 2$ & $B(2)$ & $-\mathrm{O}(1)$ & $1.83(4)$ & & & & & & \\
\hline & $-\mathrm{O}(11)$ & $2.34(2) \times 2$ & & $-\mathrm{O}(21)$ & $1.89(3)$ & & & & & & \\
\hline & $-\mathrm{O}(1)$ & $2.42(3) \times 2$ & & $-\mathrm{O}(15)$ & $2.03(4)$ & & & & & & \\
\hline$<B(1)$ & & 2.28 & & $-\mathrm{O}(22)$ & $2.37(5)$ & & & & & & \\
\hline & & & & $-\mathrm{O}(3)$ & $2.49(3)$ & & & & & & \\
\hline & & & & $-\mathrm{O}(12)$ & $2.82(3)$ & & & & & & \\
\hline & & & $<B(2)$ & $>$ & 2.24 & & & & & & \\
\hline
\end{tabular}

Table 9. Unit-cell parameters for murmanite, vigrishinite, epistolite, zvyaginite and Zn-exchanged forms of murmanite after 5- (ZnMur5h) and 24-hour (ZnMur24h) experiments.

\begin{tabular}{|c|c|c|c|c|c|c|c|c|}
\hline Mineral & $a, \AA$ & $b, \AA$ & $c, \AA$ & $\alpha,{ }^{\circ}$ & $\beta, \circ$ & $\gamma,{ }^{\circ}$ & $V, \AA^{3}$ & Reference \\
\hline Murmanite & 5.374 & 7.075 & 12.195 & 93.00 & 107.76 & 90.10 & 440.9 & Lykova et al. (2015) \\
\hline Vigrishinite & 8.743 & 8.698 & 11.581 & 91.54 & 98.29 & 105.65 & 837.2 & Pekov et al. (2013) \\
\hline Vigrishinite & 8.713 & 8.682 & 11.746 & 91.48 & 98.47 & 105.47 & 845.0 & this work \\
\hline ZnMur5h & 8.871 & 8.844 & 11.734 & 92.75 & 97.60 & 106.23 & 872.7 & this work \\
\hline ZnMur24h & 8.748 & 8.724 & 11.675 & 92.50 & 97.85 & 105.87 & 845.9 & this work \\
\hline Zvyaginite & 8.975 & 8.979 & 12.135 & 74.33 & 80.65 & 73.96 & 900.8 & Pekov et al. (2014) \\
\hline
\end{tabular}

vigrishinite, the occurrence of the smaller $\mathrm{Zn}^{2+}$ cation instead of $\mathrm{Na}^{+}$in $A(1)$ causes a decrease of the coordination number from 8 to 6 and the formation of a Zn-centred octahedron with an $\langle A(1)-\mathrm{O}\rangle$ distance of $2.17 \AA$ (Table 8, Fig. 6(b)). The mainly vacant $A(2)$ site occurs in a large cavity of the $H$ sheet and is occupied most probably by $\mathrm{Ca}$ ( $12 \%$ site occupancy). There are two low-occupancy $B(1)$ and $B(2)$ cation sites in the interlayer. Site $B(1)$ is located at the inversion centre and occupied by $\mathrm{Ca}(36 \%$ site occupancy) and $B(2)$ is occupied by $\mathrm{Zn}(15 \%)$. Assignment of $A(2)$ and $B(1)$ sites is questionable if based solely on structural data. However, the present model gives $0.4 \mathrm{Ca} a p f u$, which is in general agreement with electron-microprobe data (Table 1, analysis \#6). Moreover, the small sizes of $A(1)$ and 


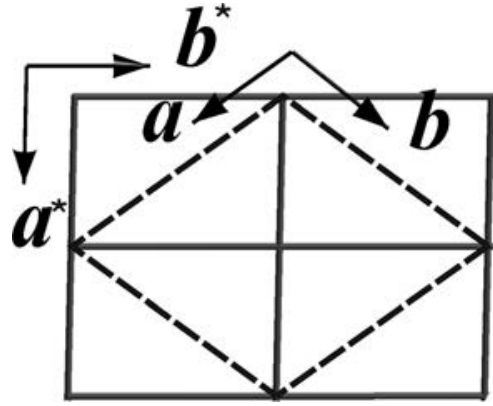

Fig. 3. Transformation of the small murmanite-type unit cell (solid line) into the vigrishinite-type unit cell (dotted line).

$B$ (2)-centred polyhedra (Table 8) allow us to assign $\mathrm{Zn}$ unambiguously to them, and to "reserve" the $A(2)$ and $B(1)$ sites as only possible for $\mathrm{Ca}$.

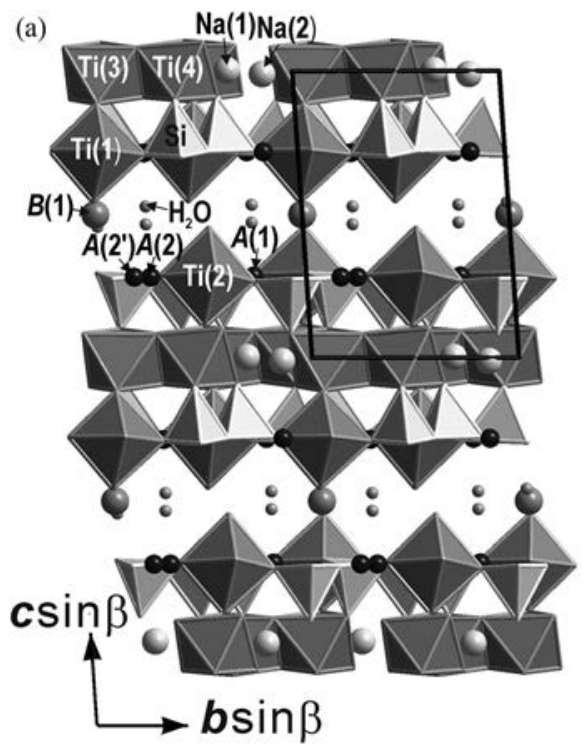

The occupancies of the $\mathrm{O}(1)-\mathrm{O}(22)$ anion sites are similar to those found in vigrishinite.

The formula obtained from the structural refinement of the 24-hour $\mathrm{Zn}$-exchanged form of murmanite is

$$
\begin{aligned}
& { }^{[B 1]} \mathrm{Zn}_{0.15}^{[B 2]} \mathrm{Ca}_{0.18}\left\{\mathrm{Na}_{1.06}\left(\mathrm{Ti}_{1.32} \mathrm{Mn}_{0.60} \mathrm{Nb}_{0.08}\right)\right\} \\
& \quad\left\{{ }^{[A 1]} \mathrm{Zn}_{0.70}^{[A 2]} \mathrm{Ca}_{0.12}\left(\mathrm{Ti}_{1.74} \mathrm{Nb}_{0.26}\right)\left[\mathrm{Si}_{2} \mathrm{O}_{7}\right]_{2}\right\} \mathrm{O}_{2}(\mathrm{OH}, \mathrm{O})_{2}\left(\mathrm{H}_{2} \mathrm{O}\right)_{4}
\end{aligned}
$$

in which the braces successively give the contents of the $O$ and $H$ sheets.

Thus, at the late stage of ion exchange $\mathrm{Zn}$ enters murmanite in considerable amounts, occupying mainly a site in the $H$ sheet and, partially, a site in the interlayer space. Calcium mobilizes again and partly moves from the $H$ sheet into the interlayer. These data are in good agreement with the crystal-structure model of

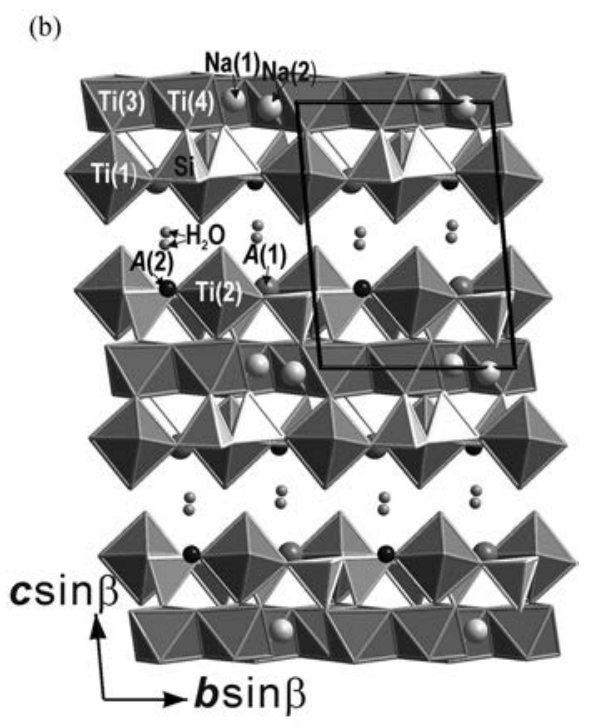

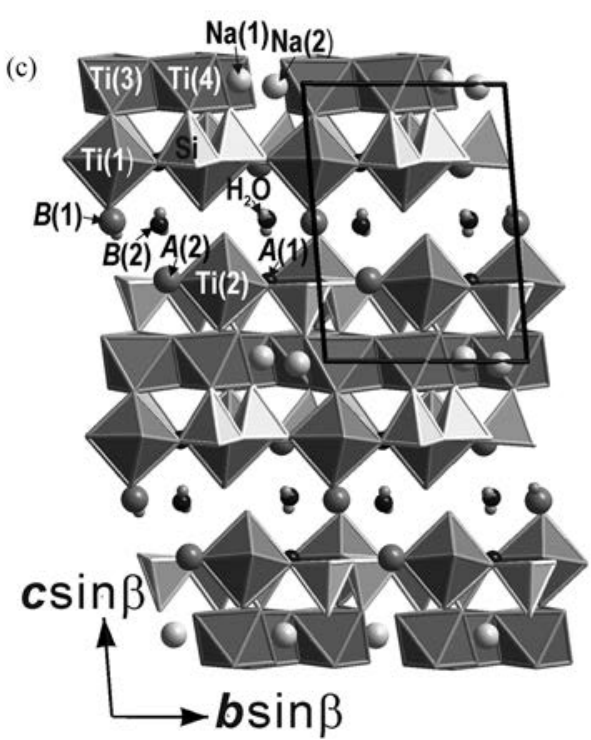

Fig. 4. Crystal structures of vigrishinite (a; this work) and the Zn-exchanged forms of murmanite after the experiments during 5 hours (b) and 24 hours (c). Unit cells are outlined. Small black spheres are Zn, large dark grey spheres are Ca. 
(a)

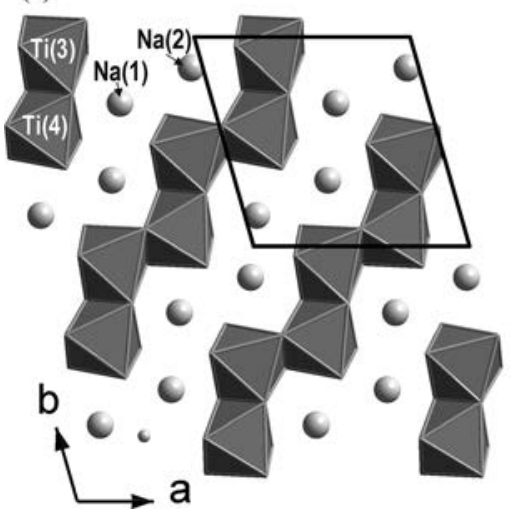

(b)

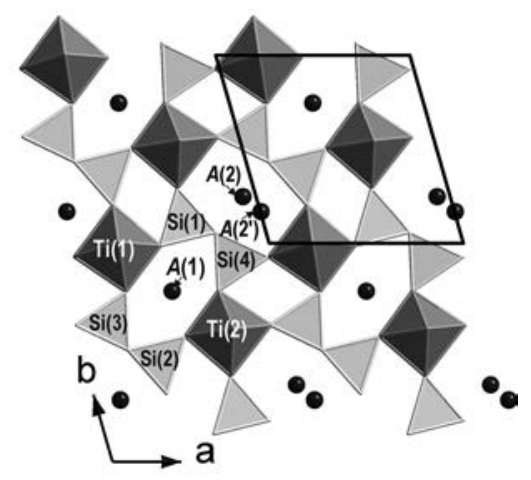

Fig. 5. The $O$ (a) and $H(\mathrm{~b})$ sheets in the structure of vigrishinite. Unit cells are outlined. For legend see Fig. 4.

(a)

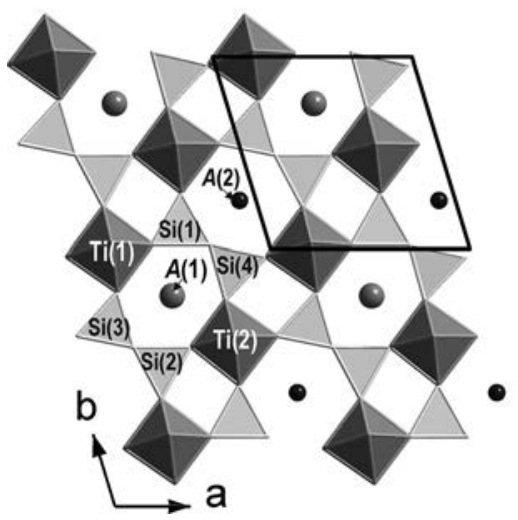

(b)

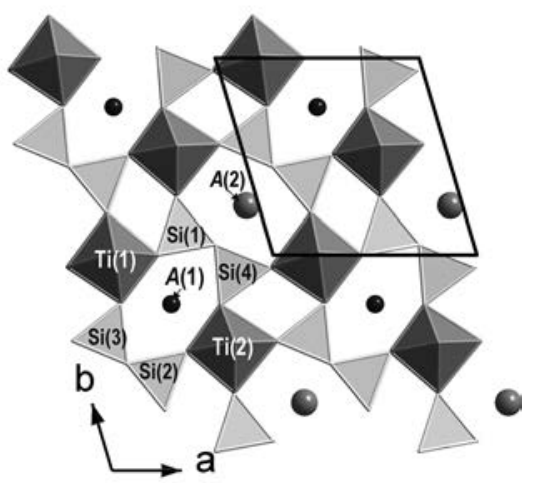

Fig. 6. The $H$ sheet in the structures of Zn-exchanged forms of murmanite after the 5 hours (a) and 24 hours (b) experiments. Unit cells are outlined. For legend see Fig. 4.

vigrishinite. The presence of the low-occupancy $B(2)$ site confirms the possibility of localization of $\mathrm{Zn}$ in the interlayer, as was suggested in the original structural model of vigrishinite (Pekov et al., 2013). One may plausibly assume that further increasing duration of the ion-exchange experiment will lead to leaching of remaining $\mathrm{Ca}$ from the $H$ sheet. Large cavities formed as a result of its leaching can additionally host small amount of "scattered" Zn, as it was found in both the new and original vigrishinite structure models.

The similarity of crystal structures of vigrishinite and the $\mathrm{Zn}$-exchanged form of murmanite after the 24 hour experiment clearly confirms the hypothesis (Pekov et al., 2013, 2014) that vigrishinite was formed as a product of natural ion exchange of $\mathrm{Na}$ for $\mathrm{Zn}$ in murmanite.

One may note that in a Zn-rich variety of another layered titanosilicate, kupletskite, zinc occupies the sites together with prevailing $\mathrm{Mn}^{2+}$ (Piilonen et al., 2006). Unlike epistolite-group minerals, in this case zinc is a primary component involved during the crystallization of kupletskite in a relatively high-temperature peralkaline pegmatite system.

\section{Conclusions}

The crystal structure of vigrishinite was revised on a new sample from the type locality. The structure data are in a good agreement with the original model and, due to the better quality of the new crystal, the arrangement of $\mathrm{Na}, \mathrm{Ca}$ and $\mathrm{Zn}$ was refined unambiguously. There are two partially vacant $\mathrm{Na}$ sites in the $O$ sheet, one $\mathrm{Zn}$-dominant and one additional low-occupancy $\mathrm{Zn}$ sites in the $H$ sheet and one low-occupancy $\mathrm{Ca}$ site in the interlayer.

The study of the $\mathrm{Zn}$-exchanged forms of murmanite obtained in ion-exchange experiments allowed us (a) to support the hypothesis, proposed by Pekov et al. (2013), that vigrishinite is a product of natural ion exchange of $\mathrm{Na}$ for $\mathrm{Zn}$ in murmanite and (b) to comprehend the exchange mechanism step-by-step. The early stage of the reaction includes complete $\mathrm{Na}^{+}$leaching from the $H$ sheet and partly from the $O$ sheet, and migration of $\mathrm{Ca}$ (a common admixture in murmanite) into one of the sites in the $H$ sheet whereas another site here remains vacant. This causes the transformation of the murmanite-type unit cell into the vigrishinite-type one and empties a site in the $H$ sheet for further entry of $\mathrm{Zn}$. In the next stage of ion exchange, $\mathrm{Zn}^{2+}$ 
enters a site in the $H$ sheet and, in small amount, a site in the interlayer space. The $\mathrm{Ca}^{2+}$ ion partly moves from the $H$ sheet into the interlayer. The simplified reaction scheme can be given as $\mathrm{Na}_{4} \mathrm{Ti}_{4}\left[\mathrm{Si}_{2} \mathrm{O}_{7}\right]_{2} \mathrm{O}_{4}\left(\mathrm{H}_{2} \mathrm{O}\right)_{4}+(2-y) \mathrm{Zn}^{2+} \rightarrow$ $\mathrm{Na}_{x} \mathrm{Zn}_{2-y} \mathrm{Ti}_{4}\left[\mathrm{Si}_{2} \mathrm{O}_{7}\right]_{2} \mathrm{O}_{2}(\mathrm{OH}, \mathrm{F}, \mathrm{O})_{2}\left(\mathrm{H}_{2} \mathrm{O}, \mathrm{OH}, \square\right)_{4}+(4-x)$ $\mathrm{Na}^{+}+n \mathrm{H}_{2} \mathrm{O}, n<1,0 \leq x \leq 2,0 \leq y \leq 1.5$.

Our data show that some details of the crystal structure of vigrishinite, such as the presence or absence of vacancies in Ti sites and of low-occupancy $\mathrm{Zn}$ sites in the interlayer, may vary from sample to sample. At the same time, the main species-defining crystal-chemical feature of vigrishinite, namely the presence of one $\mathrm{Zn}$ dominant site in the $H$ sheet, is found both in studied samples of the mineral and in the 24-hour $\mathrm{Zn}$ exchanged form of murmanite. Significant difference in ionic radii between $\mathrm{Zn}^{2+}$ and $\mathrm{Na}^{+}$leads to formation of a Zn-centred octahedron instead of a Na-centred eight-fold polyhedron in murmanite, causing the distortion of the $H$ sheet and formation of large holes that stay mainly vacant. The ordering (alternation) of $\mathrm{Zn}$ sites and holes in the $H$ sheet leads to transformation of the small, murmanite-type unit cell to the larger, vigrishinite-type one with $a$ and $b$ parameters corresponding to the $a b$ face diagonals of the former.

Recent findings of vigrishinite in two pegmatites of Lovozero (at Severnyi open pit, Mt. Alluaiv, and at Pegmatite \#60, Mt. Karnasurt) in the same situation as at the type locality at Mt. Malyi Punkaruaiv show that the ion-exchange in epistolite-group heterophyllosilicates is not uncommon and probably easily happens in Nature. Our electron-microprobe data demonstrate the existence of a continuous solid-solution series between ordinary, Znfree murmanite and vigrishinite.

New data allow us to consider the original chemical formula of vigrishinite, $\mathrm{Zn}_{2} \mathrm{Ti}_{4-x} \mathrm{Si}_{4} \mathrm{O}_{14}\left(\mathrm{OH}, \mathrm{H}_{2} \mathrm{O}, \square\right)_{8}$ with $x<1$, as an end-member of the solid-solution series. We propose to revise the anionic part of the formula, taking into account the new structural data, as $\mathrm{Zn}_{2} \mathrm{Ti}_{4-x}\left[\mathrm{Si}_{2} \mathrm{O}_{7}\right]_{2} \mathrm{O}_{2}(\mathrm{OH}, \mathrm{F}, \mathrm{O})_{2}\left(\mathrm{H}_{2} \mathrm{O}, \mathrm{OH}, \square\right)_{4}$ with $x<1$. In general, the chemical composition of the mineral varies in a wide range depending on the degree of cation exchange.

Lomonosovite also undergoes ion exchange with $\mathrm{Zn}$, but the reaction process is much slower than for murmanite and affects only a small peripheral zone of a grain in our experiments. As in the experiments with $\mathrm{Cu}$ and $\mathrm{Ag}$, the content of $\mathrm{P}$ (in atomic proportion) in the $\mathrm{Zn}$-exchanged form of lomonosovite remains the same as in the untreated mineral. Thus we can assume that in Nature the formation of vigrishinite directly from lomonosovite, without its prior transformation into murmanite, is strongly hampered or even impossible.

We assume that a process similar to the transformation of murmanite to vigrishinite is implemented in the evolution series epistolite-zvyaginite, in spite of the difference in zinc arrangement: unlike vigrishinite, zvyaginite contains $\mathrm{Zn}$ in the $O$ sheet (Pekov et al., 2014).

The strong affinity of epistolite-group minerals for chalcophile elements $(\mathrm{Zn}, \mathrm{Ag}$ and $\mathrm{Cu}$ ) in the exchange reactions allows us to consider them as possible prototypes of selective synthetic ion-exchangers.

Acknowledgements: We thank Péter Németh and an anonymous referee for their valuable comments and Sergey V. Krivovichev for his editorial input. Special thanks are due to S.V. Fedyushchenko for the support of this work. This study was supported by Russian Foundation for Basic Research, grants nos. 12-05-90831mol_rf_nr, 12-05-31212-mol_a, 13-05-12021_ofi_m and 14-05-00190-a, and by the Foundation of the President of the Russian Federation, grants nos. NSh-1130.2014.5 and MD-2088.2014.5. Support by the SPbSU X-Ray Diffraction Resource Centre is also acknowledged.

\section{Note}

1 The electron density assigned to Zn cations "spreads" over the cavity.

\section{References}

Belov, N.V., Gavrilova, G.S., Solov'eva, L.P., Khalilov, A.D. (1977): The refined structure of lomonosovite. Sov. Phys. Dokl., 235, 1064-1067. (in Russian).

Borneman-Starynkevich, I.D. (1946): On the chemical nature of murmanite. in "Problems of mineralogy, geochemistry and petrography”, D.S. Belyankin, ed. AN USSR, Moscow-Leningrad, 66-74. (in Russian).

Brese, N.E. \& O'Keeffe, N.E. (1991): Bond-valence parameters for solids. Acta Crystallogr., 47, 192-197.

Cámara, F., Sokolova, E., Hawthorne, F.C., Abdu, Y. (2008): From structure topology to chemical composition. IX. Titanium silicates: revision of the crystal chemistry of lomonosovite and murmanite, Group-IV minerals. Mineral. Mag., 72, 1207-1228.

Ferraris, G. \& Gula, A. (2005): Polysomatic aspects of microporous minerals - heterophyllosilicates, palysepioles and rhodesiterelated structures. Rev. Mineral. Geochem., 57, 69-104.

Khalilov, A.D. (1989): The refinement of murmanite crystal structure and new data on its crystallo-chemical features. Mineralogicheskiy Zhurnal, 11, 19-27. (in Russian).

Khalilov, A.D., Makarov, E.S., Mamedov, Kh.S., P'yanzina, L.Ya. (1965): On the crystal structure of minerals of the murmanitelomonosovite group. Dokl. Akad. Nauk SSSR, 162, 179-182. (in Russian).

Lykova, I.S., Chukanov, N.V., Tarasov, V.P., Pekov, I.V., Yapaskurt, V.O. (2013a): Ion exchange properties of murmanite $\mathrm{Na}_{2} \mathrm{Ti}_{2}\left(\mathrm{Si}_{2} \mathrm{O}_{7}\right) \mathrm{O}_{2} \cdot 2 \mathrm{H}_{2} \mathrm{O}$. Khimicheskaya Fizika, 32, 35-42. (in Russian).

Lykova, I.S., Chukanov, N.V., Kazakov, A.I., Tarasov, V.P., Pekov, I.V., Yapaskurt, V.O., Chervonnaya, N.A. (2013b): Murmanite and lomonosovite as $\mathrm{Ag}$-selective ionites: kinetics and products of ion exchange in aqueous $\mathrm{AgNO}_{3}$ solutions. Phys. Chem. Minerals, 40, 625-633.

Lykova, I.S., Pekov, I.V., Zubkova, N.V., Chukanov, N.V., Yapaskurt, V.O., Chervonnaya, N.A., Zolotarev, A.A, Jr. (2015): Crystal chemistry of cation-exchanged forms of epistolite-group minerals. 
Part I. Ag- and Cu-exchanged lomonosovite and Ag-exchanged murmanite. Eur. J. Mineral, 27, 535-549, doi: 10.1127/ejm/2015/ 0027-2445

Németh, P., Ferraris, G., Radnóczi, G., Ageeva, O.A. (2005): TEM and X-ray study of syntactic intergrowths of epistolite, murmanite and shkatulkalite. Can. Mineral., 43, 973-998.

Pekov, I.V. \& Nikolaev, A.P. (2013): Minerals of the pegmatites and hydrothermal assemblages of the Koashva deposit (Khibiny, Kola peninsula, Russia). Mineralogical Almanac, 18(2), 6-65.

Pekov, I.V., Britvin, S.N., Zubkova, N.V., Chukanov, N.V., Bryzgalov, I.A., Lykova, I.S., Belakovskiy, D.I., Pushcharovsky, D.Yu. (2013): Vigrishinite, $\mathrm{Zn}_{2} \mathrm{Ti}_{4-x} \mathrm{Si}_{4} \mathrm{O}_{14}\left(\mathrm{OH}, \mathrm{H}_{2} \mathrm{O}, \square\right)_{8}$, a new mineral from the Lovozero alkaline complex, Kola Peninsula, Russia. Geol. Ore Deposits, 55, 575-586.

Pekov, I.V., Lykova, I.S., Chukanov, N.V., Yapaskurt, V.O., Belakovskiy, D.I., Zolotarev, A.A., Zubkova, N.V. (2014): Zvyaginite, $\mathrm{NaZnNb}_{2} \mathrm{Ti}_{[}\left[\mathrm{Si}_{2} \mathrm{O}_{7}\right]_{2} \mathrm{O}(\mathrm{OH}, \mathrm{F})_{3}\left(\mathrm{H}_{2} \mathrm{O}\right)_{4+x}(\mathrm{x}<1)$, a new mineral of the epistolite group from the Lovozero Alkaline
Pluton, Kola Peninsula, Russia. Geol. Ore Deposits, 56, 644-656.

Piilonen, P.C., Pekov, I.V., Back, M., Steede, T., Gault, R.A. (2006): Crystal structure refinement of a Zn-rich kupletskite from Mont Saint-Hilaire, Quebec, with contributions to the geochemistry of zinc in peralkaline environments. Mineral. Mag., 70, 565-578.

Rastsvetaeva, R.K. \& Andrianov, V.N. (1986): New data on the crystal structure of murmanite. Kristallografiya, 31, 82-87. (in Russian).

Sheldrick, G.M. (2008): A short history of SHELX. Acta Crystallogr., A64, 112-122.

Sokolova, E. \& Hawthorne, F.C. (2004): The crystal chemistry of epistolite. Can. Mineral., 42, 797-806.

Received 2 March 2015

Modified version received 16 April 2015

Accepted 18 May 2015 